\title{
Viral and cellular factors underlying neuropathogenesis in HIV associated neurocognitive disorders (HAND)
}

\author{
Vasudev R Rao ${ }^{\dagger}$, Arthur P Ruiz and Vinayaka R Prasad ${ }^{*}$
}

\begin{abstract}
As the HIV-1 epidemic enters its fourth decade, HIV-1 associated neurological disorders (HAND) continue to be a major concern in the infected population, despite the widespread use of anti-retroviral therapy. Advancing age and increased life expectancy of the HIV-1 infected population have been shown to increase the risk of cognitive dysfunction. Over the past 10 years, there has been a significant progress in our understanding of the mechanisms and the risk factors involved in the development of HAND. Key events that lead up to neuronal damage in HIV-1 infected individuals can be categorized based on the interaction of HIV-1 with the various cell types, including but not limited to macrophages, brain endothelial cells, microglia, astrocytes and the neurons. This review attempts to decipher these interactions, beginning with HIV-1 infection of macrophages and ultimately resulting in the release of neurotoxic viral and host products. These include: interaction with endothelial cells, resulting in the impairment of the blood brain barrier; interaction with the astrocytes, leading to metabolic and neurotransmitter imbalance; interactions with resident immune cells in the brain, leading to release of toxic cytokines and chemokines. We also review the mechanisms underlying neuronal damage caused by the factors mentioned above. We have attempted to bring together recent findings in these areas to help appreciate the viral and host factors that bring about neurological dysfunction. In addition, we review host factors and viral genotypic differences that affect phenotypic pathological outcomes, as well as recent advances in treatment options to specifically address the neurotoxic mechanisms in play.
\end{abstract}

\section{Introduction}

HIV associated neurocognitive disorders (HAND) are a potential consequence of HIV-1 infection, and about half of all adults with AIDS suffer from neurological complications related to HIV-1 [1]. HIV-1 infection plays a pivotal role in HAND by generating products that lead to neurological damage in the central nervous system $(\mathrm{CNS})$. HAND includes a spectrum of neurological disorders ranging from asymptomatic neurocognitive impairment (ANI), an intermediate form termed mild neurocognitive disorder (MND) and the severe form, HIV associated dementia (HAD) [2]. The relationship between the prevalence of these forms to each other and their occurrence in the overall population of HIV-1-infected individuals can be depicted in a pyramidal form, with the total

\footnotetext{
* Correspondence: vinayaka.prasad@einstein.yu.edu

${ }^{\dagger}$ Equal contributors

Department of Microbiology and Immunology, Albert Einstein College of

Medicine, 1300 Morris Park Avenue, Bronx, NY 10461, USA
}

number of HIV-1-infected individuals forming the base, with the upper layers having progressively fewer numbers of patients exhibiting ANI, MND and HAD. As the availability of highly active anti-retroviral therapy (HAART) has become more widespread worldwide, HIV-1-infected individuals are living longer. Although the incidence and prevalence of HAD have been reduced in the era of HAART, the prevalence of HAND overall is actually increasing worldwide. The increased lifespan of treated patients results in a chronic exposure of the brain to HIV-1 virions and viral proteins leading to inflammation, as well as a concomitant chronic inflammation in the peripheral immune system, leading to the accumulation of neurological damage [3]. The success of HAART in controlling peripheral viral load is not necessarily accompanied by reduction in the immune activation in the brain [4]. 


\section{Overview of HIV neuropathogenesis}

Before embarking on delineating the viral and host factors that play central roles in HAND, it is helpful to have an understanding of the current working model for a mechanistic basis of HIV neuropathogenesis. Infiltration of monocytes into the brain is a hallmark of HAND [5]. Monocytederived macrophages (MDM) are one of the major types of cell that are infected by HIV-1 $\left(\mathrm{CD} 4^{+} \mathrm{T}\right.$ lymphocytes and dendritic cells being the other two cell types). Once the HIV-1-infected macrophages have established residence in the CNS, they secrete chemokines that establish a chemotaxis gradient across the blood-brain barrier (BBB), which recruits more monocytic cells from the peripheral compartment into the CNS [6]. This influx of HIV-1-infected monocytic cells leads to the infection of other CNSresident monocytic cells, namely perivascular macrophages and microglia [7], which in turn results in greater BBB damage and accelerates the rate at which HIV-1-infected and uninfected monocytic cells can enter the brain. Neurons do not support HIV-1-infection or replication, but they do express several cell-surface receptors (CCR5, CXCR4, NMDAR etc.) that render them sensitive to insults by viral proteins (e.g. Tat, gp120), inflammatory cytokines (e.g. TNF- $\alpha$, IL1 $\beta$ ) and small metabolites (e.g. nitric oxide, arachidonic acid, etc.) secreted by immune cells in the brain [8]. The key events that contribute to HAND include direct neuronal apoptosis, dysregulation of key neuronal support cells, and the loss of dendritic arbor.

\section{HIV-1 infection of Macrophages}

The process of HIV-1 infection begins by HIV-1 binding to CD4 receptor on the target cell surface, through the viral envelope protein gp120 [9]. This binding induces a conformational change in gp120 that exposes a CD4-binding induced (CD4i) co-receptor binding site, which subsequently binds to either CCR5 or CXCR4 coreceptor [10]. The binding of gp120 to a co-receptor then exposes the fusion peptide in viral protein gp41, which is inserted into the cell membrane and drives fusion of the viral and cell membranes [11]. The co-receptor preference, which is determined primarily by the V3 loop in gp120 [12], designates a given HIV-1 isolate as either an R5 or X4 virus depending upon whether it uses CCR5 or CXCR4 coreceptor. Based on the fact that CCR5 $\triangle 32$ mutation confers resistance to HIV-1 transmission [13], the field has come to the conclusion that only R5 viruses are transmissible and are the type of viruses detected systemically early in infection. However, later as the disease progresses, the predominant tropism switches to CXCR4-usage [14], at least in some of the cases (approximately 50\%). CXCR4 usage is associated with faster viral replication and a more rapid CD4 ${ }^{+}$T-cell decline [14]. However, this switch is not obligatory for disease progression, as exceptions are observed in some parts of the world where non-B subtypes of HIV-1 are prevalent [15].
HIV-1 can productively infect both $\mathrm{CD} 4^{+} \mathrm{T}$ lymphocytes and monocytic cells/macrophages. Infection of monocytic/ macrophage cells is primarily by M-tropic viruses driving fusion through the CCR5 coreceptor, but infection by T-tropic viruses through the CXCR4 coreceptor has also been observed [16]. While dendritic cells can also be infected by HIV-1, they do not support robust HIV-1 replication. However, they do play a crucial role in the systemic spread of HIV-1 due to their strategic presence in lymph nodes [17]. HIV-infection leads to a progressive decline in the population of $\mathrm{CD}_{4}^{+} \mathrm{T}$ cells, which is due to loss of both infected $\mathrm{CD}^{+}{ }^{+} \mathrm{T}$ cells and uninfected cells (bystander killing) [18]. However, there is no systemic loss of monocytic cells, either infected or uninfected. It has been reported that monocytic/macrophage-tropic viruses, in addition to bearing gp120 that is able to recognize and bind CCR5 coreceptor, have evolved the capability to infect cells with a lower density of CD4 receptors on the cell surface and a greater fusion activity [19]. Furthermore, macrophages are also characterized by the budding of virions into internal multivesicular bodies, which are vacuoles within the cells, rather than budding through the plasma membrane directly to the external medium. This mechanism allows HIV-1 to 'hide' inside the infected macrophages, making macrophages one of the latent reservoirs of HIV-1 [20].

The predominant route of CNS exposure to HIV-1 is through peripheral blood monocytic cells/macrophages that have been infected by virus and transmigrate across the blood-brain barrier (BBB) [5]. Peripheral blood monocytes are categorized into classical "resting" monocytes that express only $\mathrm{CD} 14\left(\mathrm{CD} 14^{++} \mathrm{CD} 16^{-}\right)$, intermediate monocytes that maintain high levels of CD14, while gaining CD16 positivity $\left(\mathrm{CD}_{1} 4^{++} \mathrm{CD} 16^{+}\right)$, and non-classical "activated" monocytes that express high CD16 levels and lower levels of $\mathrm{CD} 14\left(\mathrm{CD} 14^{+} \mathrm{CD} 16^{++}\right)[21]$. The $\mathrm{CD}^{++} 6^{++}$subset, while comprising only about $5-10 \%$ of the total circulating monocyte population, is overrepresented in the brains of patients with HIV encephalopathy [22,23]. $\mathrm{CD}^{2} 6^{++}$monocytes are more susceptible to HIV infection and support higher levels of viral replication [24]. Additionally, infected $\mathrm{CD} 16^{++}$monocytes have been shown to transmigrate more efficiently across the BBB in response to a chemokine gradient [25]. While $\mathrm{CD} 4^{+} \mathrm{T}$ lymphocytes have been suggested to play a role in trafficking HIV into the CNS, the vast majority of HIV-1 isolates derived from CNS tissue appear to be of macrophage-tropic lineage [26].

\section{CNS invasion: disruption of the blood brain barrier}

The BBB is located at all points of interaction between the brain tissue and blood vessels and consists of astrocytic end feet and human brain microvascular endothelial cells (HBMEC). In addition to the barrier created by HBMECs and astrocytes, pericytes envelope the abluminal side of 
endothelium and increase the selectivity of the barrier [27]. Pericyte density in the brain is much higher than that observed in other organs, thereby constituting an additional barrier [28]. The BBB maintains the sanctity of the brain's internal environment and provides an important physiologic and immunologic separation between the CNS and the peripheral circulation. HIV-1 infiltrates the BBB early after infection [29] using HIV-infected monocytic cells as a "Trojan horse" for entry into brain [30]. While low numbers of monocytes routinely enter the CNS as part of "immune surveillance" to replenish the population of resident macrophages, infection by HIV-1 increases the adherence of monocytes to endothelial cells, increasing their transmigration across the $\mathrm{BBB}$ [31]. The HIV-infected macrophages in the vicinity of the $\mathrm{BBB}$ secrete inflammatory cytokines and viral products that damage HBMECs, induce cellular oxidative stress and they also produce chemokines like CCL2 [32] that facilitate the build-up of additional immune cells near the barrier. The interplay between the secreted cytokines, viral products and HBMECs activates endothelial cells and increases surface expression of adhesion molecules on endothelial cells - which in turn accelerates the transmigration of infected macrophages across the BBB.

HIV-1 proteins Tat and gp120 both directly damage the $\mathrm{BBB}$ (Figure 1). Tat is a non-structural viral protein secreted by infected cells [33]. Tat mRNA [34], Tat protein [35] and antibodies to Tat [36] are detectable in the CNS of HIV-infected patients. Brain endothelial cells, when exposed to HIV-1 Tat, have been shown to alter the expression and distribution of tight junction proteins (claudins \& occludins) [37]. Tat treatment of HBMECs in vitro up-regulates matrix metallopeptidase-9 (MMP-9), which in turn increases the permeability of brain endothelial cells by degrading occludins [38]. In vitro twochamber models with HBMECs and astrocytes have also shown HIV-1 Tat causes dysregulation of nitric oxide production in brain endothelial cells [39] and induces secretion of CCL2, a key chemokine responsible for migration of immune cells [40].

Even though brain endothelial cells that line the BBB are not productively infected, several in vivo and in vitro studies have demonstrated that envelope glycoprotein gp120 causes a functional impairment at the BBB. The gp120 protein is found on the surface of virions and on infected cells as a homo-trimer, but gp120 is also shed from infected cells and found in soluble form as a monomer [41]. Studies involving HIV-1 gp120 transgenic mice, in which gp120 was expressed in thymocytes and the CNS, revealed that the permeability of the brain capillaries in mice is severely impaired [42]. Kanmogne et al. demonstrated, using a two-chamber BBB model, that the exposure of HBMECs to recombinant HIV-1 gp120 protein (from either X4 and R5 HIV-1 isolates) led to activation of proinflammatory and interferon-inducible genes, increased leukocyte adhesion, decreased trans-endothelial electrical resistance (TEER) and increased migration of monocytes across the barrier [43,44]. Removal of gp120 resulted in complete restoration of TEER and significant improvement in permeability. Exposure of HBMECs to

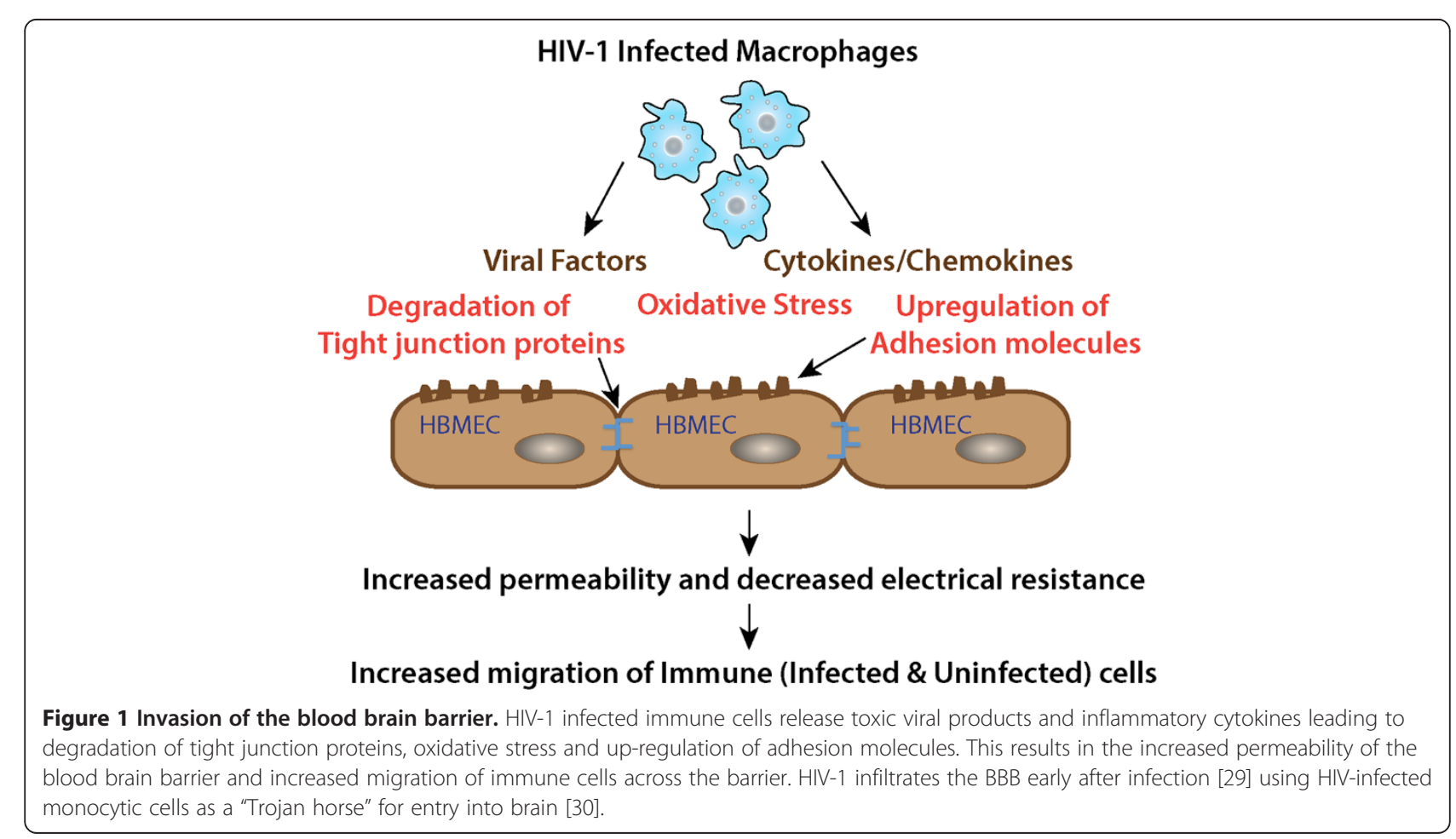


gp120 in vitro resulted in increased expression of adhesion molecules (ICAM and VCAM), damage to the barrier and a consequent increase in monocyte migration across the monolayer of endothelial cells [45]. There was a dose dependent increase in cytotoxicity of HBMECs when exposed to recombinant gp120, and gp120-mediated HBMEC cytotoxicity has been shown to involve the p38 mitogen-activated protein (MAP) kinase pathway [46].

Thus, both HIV-1 proteins gp120 and HIV-1 Tat have been implicated in perturbing the blood-brain barrier. Delineating the precise roles of additional viral and host factors that directly perturb the $\mathrm{BBB}$ as well as identifying reliable biomarkers of $\mathrm{BBB}$ damage would be crucial to furthering our understanding of the mechanisms driving the pathology specific to the BBB in HAND. Such knowledge will accelerate the development of innovative treatment strategies, specifically aimed at preventing damage to the $\mathrm{BBB}$ and reducing the CNS invasion of infected macrophages.

\section{Mechanisms of neuropathogenesis}

Although neurons cannot be infected by HIV-1, neuronal damage is a key feature in the development of HAND [47] Neurons are vulnerable to direct damage by several viral proteins. This vulnerability is mainly mediated through the presence of several neuronal cell surface receptors: the $N$-methyl-D-Aspartate receptors (NMDAR), the lowdensity lipoprotein receptor related protein (LRP), chemokine receptors CCR5 and CXCR4, and the dopamine transporter. Glutamate is the most abundant neurotransmitter in the brain, and it is responsible for propagating excitatory signal transmission by binding to NMDAR and opening cation specific channels in the cell membrane, allowing ingress of sodium and calcium ions and the egress of potassium ions [48]. LRP is a receptor involved in cholesterol trafficking in neurons, and also plays a role in signal transmission and inhibition of neuronal apoptosis [49]. Dopamine receptors and transporters are less widespread than NMDAR, but are importantly found in areas of the brain that are prone to high levels of HIV-1 infection, such as the striatum and substantia nigra, which are involved in executive function and the behavioral reward system [50], and there are lower expression levels of dopamine transporter in the striata of HIV patients with cognitive deficits [51].

The two major viral proteins that interact with the above receptors to cause neuronal injury are gp120 and Tat. Both monomeric and oligomeric gp120 have neurotoxic capabilities [52], and transgenic mice expressing gp120 have a spectrum of neuronal and glial changes resembling abnormalities in brains of HIV-1-infected humans [53]. HIV-1 gp120 directly binds NMDAR on human embryonic neurons and can cause a lethal influx of calcium ions [54] (Figure 2). HIV-1 gp120 can bind to either CCR5 or CXCR4 and induce death in neuroblastoma cells [52,55] (Figure 2). This apoptosis apparently takes place through a p38-MAPK-mediated signaling cascade [56]. Cognitive testing of gp120 transgenic mice showed age-dependent deficits in open field activity and spatial reference memory tests [57]. The natural ligands of both CCR5 (eg. CCL5, CCL3) and CXCR4 (CXCL12) were found to be neuroprotective against gp120 neurotoxicity $[52,55,58,59]$. However, CXCL12 displays neurotoxicity [56] after the N-terminal cleavage of a tetrapeptide in CXCL12 by MMP-2 [60]. Another factor up-regulated by the interaction of gp120 with CXCR4 is the neuronal nicotinic receptor $\alpha 7$, which increases cellular permeability to $\left[\mathrm{Ca}^{2+}\right]$ influx and contributes to cell death [61].

The viral protein Tat also causes neurotoxicity via multiple pathways. Similar to gp120, Tat can activate NMDA receptors and drive the toxic influx of $\mathrm{Ca}^{2+}$ ions [62] (Figure 3). In addition to calcium dysregulation through the NMDAR, Tat can induce the phospholipase C-driven activation of inositol 1,4,5-triphosphate, which increases the intracellular levels of $\left[\mathrm{Ca}^{2+}\right]$ by mobilizing stores in the endoplasmic reticulum and contributes to calcium toxicity and cell death [63]. Tat also binds LRP in neurons, causing LRP internalization and a decrease in uptake of natural LRP ligands such as amyloid- $\beta$ peptide and Apolipoprotein E [64] (Figure 3). The interaction of Tat with LRP can lead to the formation of an apoptosis-promoting complex including postsynaptic density protein-95 (PSD95), NMDA receptors and neuronal nitric oxide synthase (nNOS) [65]. Tat has been found to interfere with the expression of miRNAs in neurons, increasing the levels of CREB-targeting miR-34a and leading to neuronal dysfunction [66]. Tat can also interfere with the ability of dopamine transporter to reuptake dopamine [67]. This likely contributes to the particularly severe damage rendered to dopaminergic-rich regions in the brains of patients with severe HAND [51].

Other toxic viral proteins which have been found to activate caspases in neurons include Vpr [68] and Nef [69]. Vpu has been found to form cation-selective ion channels in a lipid bilayer membrane [70], though this effect has not been observed in neurons. Recently, stress pathways and accumulation of amyloid beta $(A \beta)$ fibrils have been reported to be important in causing neuronal dysfunction. It has been suggested that an integrated stress response (ISR) pathway involving specific ISR proteins may underlie the neuroinflammatory processes observed in HAND [71]. It has also been reported that individuals with HIV encephalitis display a higher levels of intraneuronal $A \beta$ accumulation in comparison with controls, suggesting that HIV impacts the clearance of $\mathrm{A} \beta$ in the brain [72].

Targeting the above discussed mechanisms of neuronal toxicity could yield therapies that can alleviate the 


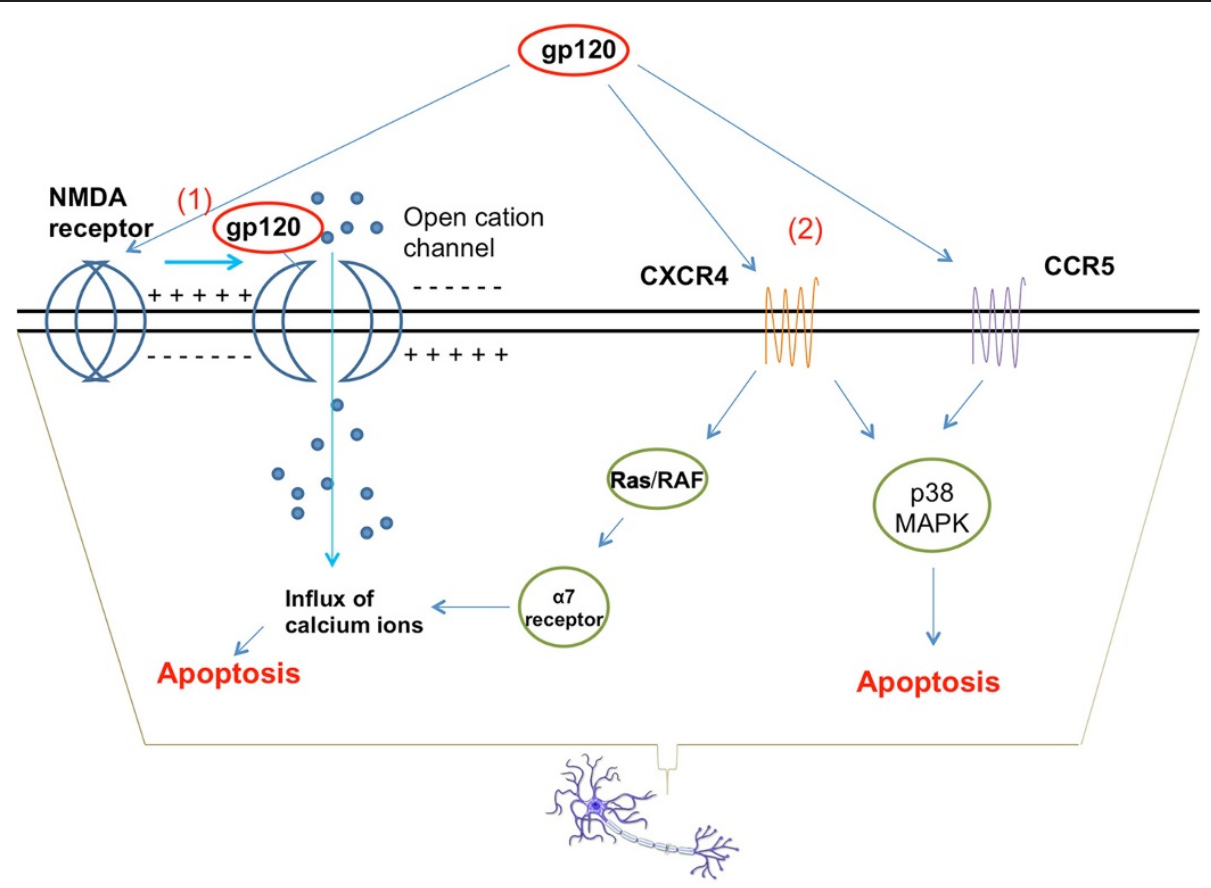

Figure 2 Mechanisms of gp120 neurotoxicity. (1) gp120 can bind to the NMDA receptor and lead to excessive opening of NMDAR-gated cation channels, allowing the influx of calcium ions to toxic levels [54]. (2) gp120 can directly bind to either CCR5 or CXCR4, activating an p38-MAPK mediated signaling cascade that leads to neuronal apoptosis [56]. The gp120-CXCR4 binding also up-regulates the expression of the nicotinic receptor a7, which increases cellular permeability to $\left[\mathrm{Ca}^{2+}\right]$ influx and contributes to cell death [61].

symptoms and improve the quality of life for patients suffering from HAND.

\section{Macrophage and microglial activation}

In addition to toxic viral proteins, HIV-1-infected macrophages and microglia release a variety of neurotoxic host factors that contribute to neuronal injury. These can be broadly categorized as proinflammatory cytokines, chemokines, and small molecules. The proinflammatory cytokines induced by HIV-1-infection of macrophages include TNF- $\alpha$, IL-1 $\beta$, IL-6, IL- 8 and IFN- $\alpha$. TNF- $\alpha$ has been shown to also inhibit glutamate uptake by astrocytes, leading to a extracellular buildup of glutamate that can lead to neuronal excitotoxicity [73]. TNF- $\alpha$ has also been found to have a neuroprotective role, through the TNFR2 mediated activation of NF-kB through a PI3 kinase [74], so its role is more complicated than simply that of a neurotoxin. IL-1 $\beta$ is released from macrophages in response to protein kinases induced by gp120 [75], and both IL-1 $\beta$ and TNF- $\alpha$ were found to dysregulate glutamate production in neurons through the induction of glutaminase [76]. IL-6 is also directly induced in macrophages by gp120, and leads to the formation of large cytoplasmic vacuoles in neurons that disrupt neuronal function [77]. Excess levels of IFN- $\alpha$ have been correlated with severity of HIV dementia [78]. Treatment of MDM with IFN- $\alpha$ (or HIV-1 infection) has been reported to increase glutaminase (GLS1) expression through phosphorylation of STAT1, which was shown to act through GLS1 promoter [79]. In addition to inflammatory cytokines, small molecules released by HIV-1-infected macrophages such as platelet activating factor (PAF) and quinolinic acid play a key role in neurotoxicity via NMDAR dysregulation $[80,81]$.

Microglia are mesoderm-derived cells whose population is established in the brain perinatally. They are responsible for immune surveillance of the CNS, and are the primary source of inflammatory cytokines in the brain [82]. Infected microglia are thought to be the main source of giant multinucleated cells, which are a hallmark of HIV associated dementia and an important source of inflammatory cytokines in the CNS of HIV-1 patients [83]. Microglia are a major source of neuronal excitotoxicity, releasing glutamate in response to HIV-1 infection [84]. Even in patients who are able to effectively control HIV infection via ART, increased microglial activation has been shown to correlate with poorer executive performance [85]. Treatment of fetal human microglia with recombinant Tat induces the production of a number of chemokines, such as CCL2 and CCL5, involved in the development of HAND [86]. Dysregulated chemokines released from microglia have an especially potent impact on neurons, due to the presence of several chemokine receptors on neuronal cell surface, including 


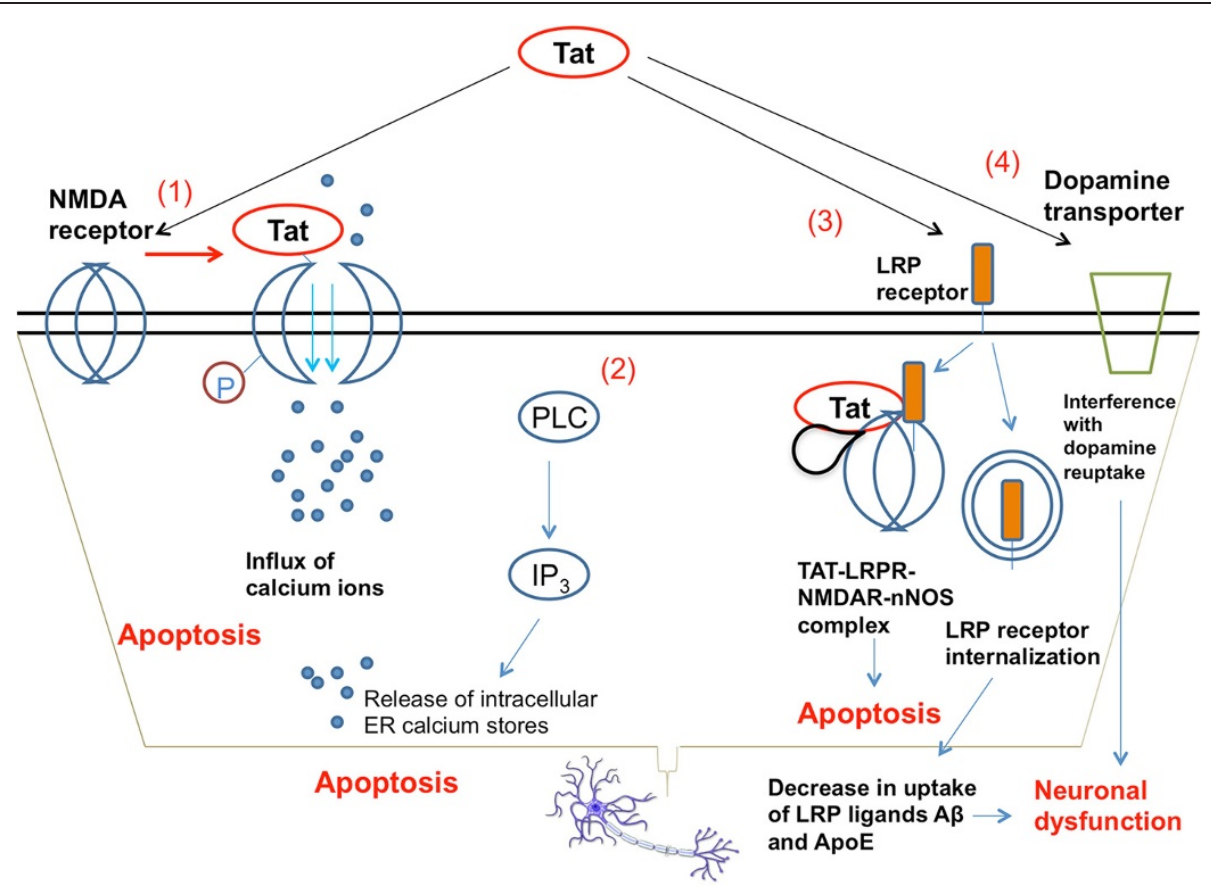

Figure 3 Mechanisms of Tat neurotoxicity. (1) Tat binds to the NMDA receptor and drives the phosphorylation of an intracellular NMDAR subunit, causing excess opening of cation channels and toxic accumulation of calcium [62]. (2) When applied to neurons, Tat is able to induce the activation of PLC and drive the IP3-mediated release of intracellular calcium from ER stores, further contributing to calcium toxicity and apoptosis [63]. (3) Tat can bind to LRP receptors, and be taken up as part of a macromolecular complex including NMDAR and neuronal nitric oxide synthase (nNOS) that induces cellular apoptosis [65]. Tat can also drive the internalization of the LRP receptor, reducing the uptake of LRP receptor ligands amyloid- $\beta$ peptide and Apolipoprotein E, which may contribute to systemic neuronal dysfunction [64]. (4) Tat interferes with the activity of dopamine transporter, diminishing the reuptake of dopamine by pre-synaptic neurons and interfering with signal transmission [67].

CCR1, CCR4, CCR5, CCR9/10, CXCR2, CXCR4, and CX3CR1 [87].

\section{Astrocytes: no longer a passive bystander}

Over the past 10 years, a significant amount of research has gone into understanding the extensive role played by astrocytes in the CNS, overturning their previous status as merely space holders, structural scaffolding, and scavengers. Their newly described roles include uptake of neurotransmitters, modulation of synaptic transmission, BBB maintenance, vaso-modulation, and long-term potentiation. The new concept of neuronal-glial intercommunication, where astrocytes play a dynamic role by integrating neuronal inputs and modulating synaptic activity, has helped us better comprehend astrocyte dysfunction in the context of HAND $[88,89]$.

It has been recently shown that astrocytes can be infected by HIV-1 in vitro, and additionally that infected astrocytes can impair BBB function [90], but the infected astrocytes are rarely seen in patient brain autopsies (although one recent study has shown 20\% of the astrocytes are infected in patients with HAD [91]). Furthermore, recombinant Tat protein has been shown to be responsible for the induction of chemokines [92], cytokines [93] and nitric oxide synthetase [94] in cultured primary human astrocytes. For example, Tat has been shown to induce astrocytes to produce plateletderived growth factor BB (PDGF-BB), which in turn induces the production of CCL2 [95]. HIV-1 Tat can also up-regulate the expression of MMP-9 via MAPK-NF$\mathrm{kB}$-dependent mechanism, and MMP-9, in turn, disrupts the BBB [96].

Exposure of astrocytes to gp120 causes up-regulation of IL- 6 and TNF- $\alpha$ [97], and increases the release of glutamate and potassium, which leads to toxic increases in calcium in neurons and astrocytes [98]. Using Affymetrix microarray analysis, Wang et al. showed that primary human astrocytes, when exposed to HIV-1 or gp120 in vitro, have an impaired ability to transport L-glutamate, and the authors ascribed this defect to transcriptional inhibition of the EAAT2 glutamate transporter gene [99]. More recently, Fernandes et al. have used an animal model to show that gp120 prevents the uptake of extracellular glutamate by astrocytes, leading to a disruption of glutamateglutamine homeostasis and a consequent impairment of memory [100]. Release of toxic cytokines, inability to take up excess glutamate and damage to the BBB make astrocytes a central offender in the pathogenesis of HAND. 


\section{Neuroprotective factors}

Macrophages, microglia and even neurons themselves produce a number of neuroprotective mediators of inflammation. Neurotoxicity seen in HAND is the net result of the effects of neurotoxic insults and the action of neuroprotective host factors. In the quest to define neurotoxic agents responsible for HAND, the neuroprotective processes often go unnoticed. Platelet derived growth factor (PDGF) confers neuroprotection against gp120 toxicity by stimulating the PI3K/Akt pathway [101], and the pretreatment of neuronal cells with PDGF-CC abrogated Tat-mediated neurotoxicity by mitigating apoptosis and neurite loss [102]. Astrocytes exposed to HIV-1 or chronically infected with HIV-1 express the tissue inhibitor of metalloproteinases-1 (TIMP-1), which is shown to have a neuroprotective role when primary human neurons are exposed to HIV-1 [103]. It has also been reported that exposure of astrocytes to HIV-1 gp120 induces the expression of nuclear factor erythroid-derived 2-related factor 2 (Nrf2), which plays a role in the stimulation of antioxidant defensive enzymes [104].

Fractalkine (FKN/CX3CL1) is a chemokine produced by neurons, and it plays an important role in communication with microglia, which abundantly expresses the FKN receptor CX3CR1 (neurons also express this receptor but less abundantly). FKN plays an important role in neuroprotection and helps reduce gp120 toxicity via activation of ERK1/2 and CREB (this effect was seen both in the presence and absence of co-cultivated glial cells) [105]. Increased levels of FKN were found in the neurons of patients with HIV encephalitis, and FKN was found to potently drive the migration of monocytes across an in vitro trans-well system, as well as inhibit the neurotoxic effects of Tat protein in rat cerebellar neurons [106]. Also the chemokine CCL3L1 protects against gp120 neurotoxicity by phosphorylation of CREB, which promotes the transcription of the cell-survival gene bcl-2 [107]. The routes of action of these host mediators against viral neurotoxins may offer potential avenues of therapeutic intervention that capitalize on existing pathways of neuroprotection.

\section{Host genetic determinants of neurotoxicity}

Several important host gene polymorphisms have been associated with an effect on the transmission of HIV-1 and/or AIDS disease progression (e.g., CCR5- $\Delta 32$ [108], CCL31 [109]). Similarly, several host gene polymorphisms have been linked with effects on the susceptibility to neurocognitive impairment. A point mutation identified in CCR2 (V64I) that had been associated with slower immunosuppressive disease progression [110], has also been shown to be specifically associated with a slower progression of neurocognitive impairment [111]. This V64I variant was not associated with a difference in plasma or CSF viral load, suggesting that its impact could be mediated through a mis-regulation of the inflammatory response rather than through differences in viral replication. A polymorphism in the TNF- $\alpha$ gene increases its production in response to bacterial LPS, and this allele has been found in an increased frequency of patients with HAD [112]. An allele of CCL2, 2578G confers a 50\% reduction in risk of acquiring HIV-1 infection. However, the same allele, subsequent to HIV infection, was also associated with a 4.5 fold increased risk of HAD [113]. This 2578G allele resulted in a greater transcriptional output of CCL2, which could exacerbate the development of HAND by increasing the influx of monocytic cells in response to CNS infection.

\section{HAND co-morbidity with drugs of abuse}

Neurocognitive disease in HIV-patients can be greatly exacerbated by abuse of drugs such as opiates, methamphetamine and cocaine. Injection drug users (IDUs) are at particular risk, as injection drug use remains an important route of HIV-1 transmission [114]. In addition, HIVpatients addicted to drugs of abuse are less likely to adhere to antiretroviral drug regimens. Opioid abuse is associated with faster HIV-1 disease progression, including increased risks of neurocognitive problems. While the "typical" opioid abuser has previously been perceived as a heroin IDU, there is a growing problem with the rising numbers of people abusing prescription opiates - a 2008 report indicated that while 400,000 Americans used heroin within one year, an estimated 12 million Americans abused prescription opiates within the same timeframe [115]. The mechanisms of opioid-mediated injury in conjunction with HIV-CNS infection are well documented. $\mu$-opiod receptor (MOR) is one of the primary routes of opiod signaling [116]. While morphine itself leads to the downregulation of MOR in cultured microglia, treatment of microglia with morphine and Tat reverses this downregulation, providing a potential feed-forward mechanism of higher numbers of MOR at the cell-surface available to propagate further morphine-Tat mediated neurotoxicity [117]. Doxycycline-inducible Tat transgenic mice (that express HIV-1 Tat in astrocytes) that were administered both doxycycline and morphine showed a marked decrease in the density of dendritic spines in the striatum, compared with mice given either doxycycline or morphine alone [118]. PDGF-BB was also able to protect human neurons from synergistic Tat/morphine damage by inhibiting production of ROS and caspase- 3 through the activation of the PI3K pathways [119].

Morphine also acts synergistically with gp120 to promote neuronal death through p38 MAP kinase signaling [120]. Mice that were transgenic for gp120 and subjected to morphine withdrawal failed to normalize oxidative capacity compared with non-transgenic mice subjected to morphine withdrawal. The same study also found failure 
to recover from synaptic damage in gp120-transgenic mice experiencing withdrawal compared with non-transgenic mice [121]. Tat-induced release of CCL2 from astrocytes is further enhanced by morphine, and can increase the chemotactic migration of a microglial cell line towards affected astrocytes [122]. HIV-1 patients using opiates were found to have higher levels of microglial activation in their brains [123]. There is also evidence of opioid use having an effect on HIV-1 infection and replication: morphine significantly enhanced the infectivity of human macrophages, possibly by an increase in CCR 5 expression [124]. A more recent study showed that treatment of monocytes with morphine down-regulated several antiHIV-1 microRNAs, which rendered the monocytes more susceptible to infection [125]. Administration of morphine to rhesus macaques before infection with SIV resulted in a higher viral set point compared with a non-morphine control group [126].

Methamphetamine (METH) use has been found to exacerbate brain injury and neuronal loss in HIV-1 patients, particularly in populations of interneurons in dopamingeric areas (DA) where the drug acts on the behavioral reward system [127]. METH potentiates a Tat-mediated decrease in dopaminergic release in the cultured human fetal neurons [128]. In the human neuroblastoma cell line SH-SY5Y, treatment with both METH and Tat produced significantly higher levels of both apoptosis and formation of autophagosomes than either factor by itself [129]. In cultured human astrocytes, METH was found to potentiate the gp120-mediated release of the pro-inflammatory cytokine IL-6, mediated through the PI3K/Akt and NF-kB pathways [130]. Treatment of METH on astroglioma cells transfected with a Tat expression construct exacerbated Tat-induced down-regulation of the neuroprotective factor $\beta$-catenin [131]. Furthermore, HIV-patients using METH were found to have significantly higher viral loads than non-METH users. This was found to be a result of the interference of METH with antiretroviral therapy [132]. METH also interferes with the normal antigen processing and phagocytic functions of macrophages [133], enhances the susceptibility of macrophages to HIV-1 infection by up-regulation of CCR5 [134] and increases HIV-1 replication in CD4 T cells and monocytes [135].

Cocaine is also known to accelerate the pathology of HAND. The drug binds the dopamine transporter and reduces the rate of dopamine uptake. Cocaine potentiates Tat-mediated neurotoxicity through the action at D1 receptors [136], Cocaine administration to SHIVinfected simian macrophages enhanced viral replication through increases in NF- $\mathrm{KB}$ signaling and IL-10 [137], and cultured human endothelial cells exposed to cocaine experienced an up-regulation in adhesion molecules, resulting in increased monocyte transmigration across the BBB [138].
Interestingly, according to recent studies cannabinoids (CB) appear to actually mediate a degree of neuroprotection in the context of CNS-HIV-1 damage. Synthetic CBs acting on the $\mathrm{CB} 2$ receptor (CB2-R) were able to mitigate gp120-induced damage in both human dopaminergic neurons and CB-2R expressing microglia [139], and a CB2 agonist was found to rescue deficits in neurogenesis seen in gp120-expressing transgenic mice [140].

\section{Viral genetic determinants}

HIV-1 is phylogenetically divided into four groups: $\mathrm{M}, \mathrm{N}, \mathrm{O}$ and $\mathrm{P}$, each representing a successful zoonotic event from primates - group $M$ being the most widespread. Group $M$ is further divided into subtypes A, B, C, D, F, G, H, J, K as well as a number of circulating recombinant forms (CRFs) of these subtypes. The global distribution of HIV-1 subtypes is region-specific, with a given geographical region correlating with the presence of a distinct subtype, a CRF or a particular combination of subtypes and CRFs [141]. Such a highly region-specific distribution is thought to be due either to a founder effect, to host-population genetics selecting for specific subtypes of HIV-1, or a combination of both [142]. Region-specific subtype-distribution has allowed researchers to correlate region-specific disease severity to subtype-specific viral gene polymorphisms, as documented in clinical studies. For example, reports from India, where HIV-1 subtype $\mathrm{C}$ is the predominant subtype, pointed to a lower incidence $(0-4 \%)$ of severe forms of HAD [143,144], in contrast to geographic regions where subtype B HIV-1 is prevalent, which reported pre-HAART incidence levels of $15-30 \%$ [145,146].

Our laboratory previously investigated whether genetic differences between the circulating isolates are responsible for the wide variation in incidence of HAD in different geographic regions. We reported that a majority (88\%) of HIV-1 subtype $\mathrm{C}$ isolates worldwide have a Tat protein with a Cys31Ser polymorphism that disrupts a dicysteine motif, which is a key element of Tat protein's homology to $\beta$-chemokines [147] (Figure 4). In contrast, the Tat proteins encoded by $99 \%$ of non-subtype C HIV-1 isolates maintained a C31 residue at that position. We demonstrated that Tat protein of subtype C HIV-1 isolates with a C31S polymorphism is defective for monocyte chemotaxis function in vitro [147]. As the infiltration of monocytic cells to the brain is a hallmark of HAD and plays a central role in triggering the inflammatory onslaught on neurons, we hypothesized that the C31S polymorphism in Tat protein of subtype C HIV-1 isolates contributes to the mechanistic basis for low incidence of HAD reported in India, as fewer monocytic cells would migrate to brain and result in little neuronal damage.

In subsequent studies, several other groups have showed that recombinant subtype $\mathrm{C}$ Tat protein has a decreased potential for direct neurotoxicity $[149,152]$ and a decreased 
(1) Monocytes/Macrophages

(4) Neurons

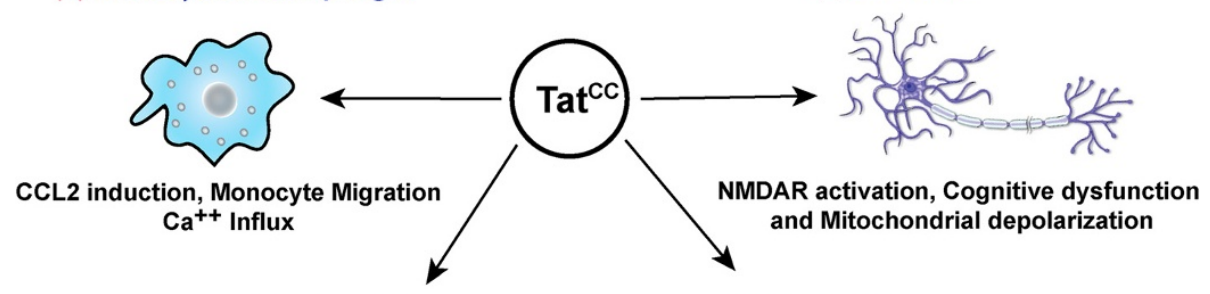

(2) Microglia

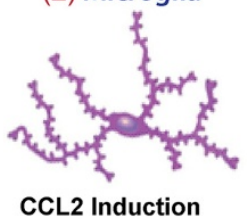

CCL2 Induction and increased CD40 expression
(3) Astrocytes

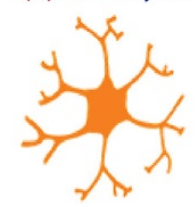

CCL2 Induction and Astogliosis

Figure 4 Contribution of the dicysteine motif in Tat to neuropathogenesis. (1) Tat is secreted by infected macrophages and microglia in the vincity of the blood brain barrier resulting in damage to the integrity of the barrier. Dicysteine Tat can act as a ligand on certain chemokine receptors expressed by circulating monocytes (i.e. CCR2, CCR3, CCR5), and promote monocyte migration across the BBB into the CNS [148]. Clade C Tat lacking the intact dicysteine motif fails to attract monocytes in a two chamber migration assay [149]. (2) Dicysteine Tat (TatB but not TatC) also induces higher expression of CCL2 and activation marker CD40 in microglial cells than non-dicysteine Tat [150]. (3) When applied to astrocytes, dicysteine Tat induces higher levels of CCL2 [149] and in HIVE SCID Mouse model astrogliosis is more pronounced in the presence of HIV-1 with an intact dicysteine motif [151]. (4) In neurons, it has been proposed that the Cys31 in the Tat dicysteine motif specifically disrupts the disulfide bond between Cys 744 and Cys 798 on the NR1 subunit of the NMDA receptor, leading to persistent activation of the NMDA receptor [152]. The increase in Tat-mediated apoptosis in dicysteine Tat is also seen in human primary neurons (mediated by increased levels of cleaved caspase-3), in addition to higher levels of ROS and increased levels of mitochondrial depolarization [149]. Primary Human neurons exposed to viral supernatants from HIV-1 with intact dicysteine motif exhibit neuronal apoptosis and HIV-1 SCID mice exposed to the same supernatants have cognitive dysfunction [151].

ability to induce inflammatory chemokine and cytokines [153-155]. In order to examine whether the C31S polymorphism is associated with biological differences in neuropathogenesis, we compared cognitive dysfunction and pathological changes induced by representative subtype $\mathrm{C}$ and B isolates in a SCID mouse HIV encephalitis (SCIDHIVE) model [155]. This allowed us to compare two genetically distinct HIV-1 isolates employing a single host genetic background. These studies revealed that subtype $\mathrm{C}$ isolates with a C31S polymorphism have lower potential to cause neuropathology and cognitive dysfunction [155] (Figure 4). In primary monocytes, subtype B Tat was found to induce higher amounts of pro-inflammatory factors than subtype C Tat, such as TNF, IL-6, CCL2, and IDO (an enzyme in the kynurenine pathway that leads to production of neurotoxic quinolinic acid) [153]. HIV-1 TatB has also been shown to disrupt the integrity of brain microvascular endothelial cells to a greater extent compared to Tat C [156]. Also, TatB, compared with TatC, can induce higher levels of IDO in human primary astrocytes [157], and TatB also induces higher levels of CCL2 in microglia [150] and primary astrocytes than TatC (this higher CCL2 induction was specifically associated with the presence of the dicysteine motif) [149] (Figure 4). Astroglioma cells that were either transfected with a Tat expression construct or treated with recombinant Tat showed a decrease in $\beta$-catenin, a transcriptional coactivator in the Wnt signaling pathway involved in neuroprotection. This $\beta$-catenin decrease was specific to the dicysteine motif in Tat, as neither TatC nor a TatB mutant with a disrupted dicysteine motif (C30G) were able to bring about this decrease [158].

The low incidence of HAD caused by subtype C HIV-1 in India was further corroborated by the absence of HAD in Ethiopia, as measured by neurocognitive tests using International HIV Dementia (IHD) scale. Subtype C HIV-1 is also widespread in the Southern African countries. Interestingly, however, recent cohort studies in South Africa and Botswana, where $\mathrm{C}$ is the predominant subtype, showed that the incidence of HAD is much higher than that in India at 25 and 38\% respectively [159-162]. In light of our earlier findings indicating reduced neuropathogenicity for subtype C HIV-1 [155], we were intrigued by the increased incidence data reported for subtype C HIV-1 cohorts in Southern Africa. While it may be generally assumed that subtype C HIV-1 from different regions of the world are highly related, studies on the phylogenetic and molecular clock analysis of gp120 sequences of Indian HIV-1 isolates have shown that their origin in India occurred much later than that of South African subtype C HIV-1 [163,164]. Therefore, we initiated a multi-site study to investigate phylogenetic differences between Southern African (South Africa and Zambia) and South Asian (India and Bangladesh) subtype C HIV-1 isolates. Our results showed that, with respect to both the whole virus genome sequence as well as 
sequences encoding Tat protein, the Indian HIV-1C isolates are genetically distinct from those in Southern Africa. More importantly, HIV-1C isolates with an intact dicysteine motif in Tat protein (C31) were quite rare (2 $3 \%$ ) in India, while they were significantly more frequent in the Southern African countries (11 - 26\%). Thus, the frequency of HIV-1C isolates with a C31 in Tat broadly paralleled the incidence of HAD in these countries. Neurocognitive tests in SCID-HIVE mice, using a representative subtype $\mathrm{C}$ from Southern Africa $\left(\mathrm{HIV}-1_{1084 i}\right)$ with an intact dicysteine motif in Tat (C31) and comparing it to subtype

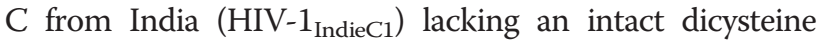
motif in Tat (C31S), showed that mice exposed to subtype C from Southern Africa exhibited significantly greater cognitive dysfunction compared to subtype $\mathrm{C}$ from India [151], especially when the testing paradigm presented a higher level of memory load. These findings lead to three main conclusions. One, intra-subtype variation exists and such variation can involve viral genes in HIV-1 that play a direct role in neurotoxicity. Two, it is more accurate to correlate differential disease outcomes in two geographical regions being compared, to differences in neurovirulence signatures rather than to differences in subtypes as a whole. Three, once further confirmed in a clinical study, it should be possible to perform a genetic screening in a subtype $\mathrm{C}$ HIV-1 epidemic for Tat genotype to gauge the risk of neurological dysfunction at the time of initial diagnosis.

Additional genetic determinants in Tat, other than C31, that play a crucial role in the pathogenesis of HAND are unknown, but are likely to exist. Further studies on differential neuropathogenesis potential of HIV-1 variants in different geographic regions will be informative. Similarly, considering the fact that gp120 causes neuropathogenesis via multiple pathways, it is also possible that there are genetic differences in gp120 between viral variants in their ability to cause HAND via gp120-mediated neurotoxicity. Identification of such variants and their impact on the pathogenesis of HAND will help dissect the various types of neurotoxic insults involving different cellular receptors and develop better therapeutics and/or diagnostics.

\section{Treatment modalities for HAND}

HAART significantly lowers the viral load in both the periphery and the CNS, and has been crucial in significantly decreasing the incidence and prevalence of severe forms of HAND [165]. However, recent clinical studies and a meta-analysis $[1,166,167]$ in patients on HAART revealed milder forms of neurological dysfunction (ANI \& MND) in greater than half of HIV-positive patients. In studies examining individuals with ART-controlled HIV viremia, HIV DNA in PBMCs correlated with regional brain atrophy highlighting the contribution of peripheral viral reservoirs to CNS pathology [168]. Even the modified HAART regimens that include drugs with better
CNS penetration effectiveness (CPE) scores, termed neuro-HAART, have had limited success among patients [169-171]. Researchers have suggested various approaches to targeting latent CNS HIV reservoirs and sources of neuroinflammation such as cytokines, chemokines and oxidative stress that are in play inside the CNS and are refractory to antiretrovirals. Use of anti-inflammatory and anti-excitotoxic drugs like Minocycline (second-generation tetracycline derivative) [172] and Memantine (voltage-dependent, open channel NMDAR blocker) [173], that can cross the BBB at substantial levels and that have been shown to be neuroprotective in SCID HIVE mice and SIV models, are currently being investigated as adjuvants to treat HAND. Several neuroprotective factors, both endogenous (as discussed above) and exogenous (e.g., pDING; [174]) are also being proposed as alternate treatments, with a focus towards eliminating neuroinflammation caused by exposure to HIV-1 [101-103]. Intranasal delivery of neurotropic protective factors such as insulin, IGF-1 and neurotrophin has been shown to mitigate many of the behavioral and pathological deficits in gp120 transgenic mice [175]. In vitro studies, using innovative delivery techniques such as gold and lipid based nano-particles, have been shown to be effective in delivering HAART and anti-inflammatory/anti-excitotoxic agents across the blood brain barrier [176] to specifically target CNS reservoirs. NanoART treatments in humanized mice reduced viral loads and protected CD4 T-cell populations [177]. Natalizumab, a monoclonal antibody against alpha-4-integrin known to block trafficking of leukocytes across the blood-brain barrier, has been shown to be effective in preventing HIV-1 infected cells from breaching the BBB in a SIV model by Campbell and colleagues [178]. These new and innovative treatments, in combination with Neuro-HAART, could be useful in treating HAND in the aging at-risk HIV-1 infected population. Thus, current approaches to intervention of HAND include not only the careful choice of antiretrovirals with better CNS penetration and efficacy, but also the future use of neuroprotective agents or the modulation of neuroprotective host factors.

\section{Conclusions}

Our precise understanding of host factors that mediate the neurotoxic insult launched by exposure of CNS to HIV1-infected cells, HIV-1 or specific HIV-1 proteins has increased in the recent past. In addition to increased knowledge about the pathways of neurotoxicity, we are also learning about the regional genetic variations in viral genes leading to intra-clade, region specific differences in disease severity. The discussion above clearly indicates that numerous opportunities exist to specifically block the neurotoxicity of viral and host proteins as well as potential neuroprotective factors that could be augmented to help alleviate the negative impact of HIV-1 on the brain. 


\section{Abbreviations}

CNS: Central nervous system; HAND: HIV-1 associated neurological disorders; ANI: Asymptomatic neurocognitive impairment; MND: Mild neurocognitive disorder; HAD: HIV-1 associated dementia; HAART: Highly active anti-retroviral therapy; ART: Anti-retroviral therapy; BBB: Blood-brain barrier; HBMEC: Human brain microvascular endothelial cells; MAP: Mitogen-activated protein; NMDAR: N-methyl-D-Aspartate receptors; LRPR: Lipoprotein receptor related protein receptors; PAF: Platelet activating factor; PDGF: Platelet derived growth factor; CRFs: Circulating recombinant forms; SCID-HIVE: SCID mouse HIV-1 encephalitis; CPE: CNS penetration effectiveness.

\section{Competing interests}

The authors declare that they have no competing interests.

\section{Authors' contributions}

All three authors wrote sections of the manuscript. VRR developed the arrangement of the various sections and VRP was responsible for the integration of the sections. All authors read and approved the final manuscript.

\section{Acknowledgements}

The authors would like to thank Eliseo Eugenin (Rutgers University) and Lisa Baker for critically reading the manuscript. VRP would like to acknowledge support from NIH R01 MH083579.

Received: 4 January 2014 Accepted: 8 May 2014

Published: 19 May 2014

\section{References}

1. Heaton RK, Franklin DR, Ellis RJ, McCutchan JA, Letendre SL, Leblanc S, Corkran SH, Duarte NA, Clifford DB, Woods SP, Collier AC, Marra CM, Morgello S, Mindt MR, Taylor MJ, Marcotte TD, Atkinson JH, Wolfson T, Gelman BB, McArthur JC, Simpson DM, Abramson I, Gamst A, Fennema-Notestine C, Jernigan TL, Wong J, Grant I, Group C, Group H: HIV-associated neurocognitive disorders before and during the era of combination antiretroviral therapy: differences in rates, nature, and predictors. J Neurovirol 2011, 17(1):3-16.

2. Antinori A, Arendt G, Becker JT, Brew BJ, Byrd DA, Cherner M, Clifford DB, Cinque P, Epstein LG, Goodkin K, Gisslen M, Grant I, Heaton RK, Joseph J, Marder K, Marra CM, McArthur JC, Nunn M, Price RW, Pulliam L, Robertson KR, Sacktor N, Valcour V, Wojna VE: Updated research nosology for HIV-associated neurocognitive disorders. Neurology 2007, 69(18):1789-1799.

3. Canizares S, Cherner M, Ellis RJ: HIV and Aging: Effects on the Central Nervous System. Semin Neurol 2014, 34(1):27-34.

4. Airoldi M, Bandera A, Trabattoni D, Tagliabue B, Arosio B, Soria A, Rainone V, Lapadula G, Annoni G, Clerici M, Gori A: Neurocognitive impairment in HIV-infected naive patients with advanced disease: the role of virus and intrathecal immune activation. Clin Dev Immunol 2012, 2012:467154.

5. Gendelman HE, Orenstein JM, Baca LM, Weiser B, Burger H, Kalter DC, Meltzer MS: The macrophage in the persistence and pathogenesis of HIV infection. AIDS (London, England) 1989, 3(8):475-495.

6. Ho WZ, Cherukuri R, Douglas SD: The macrophage and HIV-1. Immunol Ser 1994, 60:569-587.

7. Resnick L, Berger JR, Shapshak P, Tourtellotte WW: Early penetration of the blood-brain-barrier by HIV. Neurology 1988, 38(1):9-14.

8. Gendelman HE, Lipton SA, Tardieu M, Bukrinsky MI, Nottet HS: The neuropathogenesis of HIV-1 infection. J Leukoc Biol 1994, 56(3):389-398.

9. Matthews TJ, Weinhold KJ, Lyerly HK, Langlois AJ, Wigzell H, Bolognesi DP: Interaction between the human T-cell lymphotropic virus type IIIB envelope glycoprotein gp120 and the surface antigen CD4: role of carbohydrate in binding and cell fusion. Proc Natl Acad Sci U S A 1987, 84(15):5424-5428.

10. Moore JP, Trkola A, Dragic T: Co-receptors for HIV-1 entry. Curr Opin Immunol 1997, 9(4):551-562.

11. Gallo SA, Finnegan CM, Viard M, Raviv Y, Dimitrov A, Rawat SS, Puri A, Durell S, Blumenthal R: The HIV Env-mediated fusion reaction. Biochim Biophys Acta 2003, 1614(1):36-50

12. Xiao L, Owen SM, Goldman I, Lal AA, de Jong JJ, Goudsmit J, Lal RB: CCR5 coreceptor usage of non-syncytium-inducing primary HIV-1 is independent of phylogenetically distinct global HIV-1 isolates: delineation of consensus motif in the V3 domain that predicts CCR-5 usage. Virology 1998, 240(1):83-92.

13. Huang Y, Paxton WA, Wolinsky SM, Neumann AU, Zhang L, He T, Kang S, Ceradini D, Jin Z, Yazdanbakhsh K, Kunstman K, Erickson D, Dragon E, Landau NR, Phair J, Ho DD, Koup RA: The role of a mutant CCR5 allele in HIV-1 transmission and disease progression. Nat Med 1996, 2(11):1240-1243.

14. Connor Rl, Sheridan KE, Ceradini D, Choe S, Landau NR: Change in coreceptor use correlates with disease progression in HIV-1-infected individuals. J Exp Med 1997, 185(4):621-628.

15. Ping LH, Nelson JA, Hoffman IF, Schock J, Lamers SL, Goodman M, Vernazza P, Kazembe P, Maida M, Zimba D, Goodenow MM, Eron JJ Jr, Fiscus SA, Cohen MS, Swanstrom R: Characterization of V3 sequence heterogeneity in subtype $C$ human immunodeficiency virus type 1 isolates from Malawi: underrepresentation of X4 variants. J Virol 1999, 73(8):6271-6281.

16. Yi Y, Isaacs SN, Williams DA, Frank I, Schols D, De Clercq E, Kolson DL, Collman RG: Role of CXCR4 in cell-cell fusion and infection of monocyte-derived macrophages by primary human immunodeficiency virus type 1 (HIV-1) strains: two distinct mechanisms of HIV-1 dual tropism. J Virol 1999, 73(9):7117-7125

17. Wu L, KewalRamani VN: Dendritic-cell interactions with HIV: infection and viral dissemination. Nat Rev Immunol 2006, 6(11):859-868.

18. Finkel TH, Tudor-Williams G, Banda NK, Cotton MF, Curiel T, Monks C, Baba TW, Ruprecht RM, Kupfer A: Apoptosis occurs predominantly in bystander cells and not in productively infected cells of HIV- and SIV-infected lymph nodes. Nat Med 1995, 1(2):129-134.

19. Thomas ER, Dunfee RL, Stanton J, Bogdan D, Taylor J, Kunstman K, Bell JE, Wolinsky SM, Gabuzda D: Macrophage entry mediated by HIV Envs from brain and lymphoid tissues is determined by the capacity to use low CD4 levels and overall efficiency of fusion. Virology 2007, 360(1):105-119.

20. Orenstein JM, Meltzer MS, Phipps T, Gendelman HE: Cytoplasmic assembly and accumulation of human immunodeficiency virus types 1 and 2 in recombinant human colony-stimulating factor-1-treated human monocytes: an ultrastructural study. J Virol 1988, 62(8):2578-2586.

21. Ziegler-Heitbrock L, Ancuta P, Crowe S, Dalod M, Grau V, Hart DN, Leenen PJ, Liu YJ, MacPherson G, Randolph GJ, Scherberich J, Schmitz J, Shortman K, Sozzani S, Strobl H, Zembala M, Austyn JM, Lutz MB: Nomenclature of monocytes and dendritic cells in blood. Blood 2010, 116(16):e74-e80.

22. Fischer-Smith T, Croul S, Sverstiuk AE, Capini C, L'Heureux D, Regulier EG, Richardson MW, Amini S, Morgello S, Khalili K, Rappaport J: CNS invasion by CD14+/CD16+ peripheral blood-derived monocytes in HIV dementia: perivascular accumulation and reservoir of HIV infection. $J$ Neurovirol 2001, 7(6):528-541.

23. Pulliam L, Gascon R, Stubblebine M, McGuire D, McGrath MS: Unique monocyte subset in patients with AIDS dementia. The Lancet 1997, 349(9053):692-695.

24. Ellery PJ, Tippett E, Chiu YL, Paukovics G, Cameron PU, Solomon A, Lewin SR, Gorry PR, Jaworowski A, Greene WC, Sonza S, Crowe SM: The CD16+ monocyte subset is more permissive to infection and preferentially harbors HIV-1 in vivo. J Immunol 2007, 178(10):6581-6589.

25. Williams DW, Calderon TM, Lopez L, Carvallo-Torres L, Gaskill PJ, Eugenin EA, Morgello S, Berman JW: Mechanisms of HIV entry into the CNS: increased sensitivity of HIV infected CD14 + CD16+ monocytes to CCL2 and key roles of CCR2, JAM-A, and ALCAM in diapedesis. PLoS One 2013, 8(7):e69270.

26. Schnell G, Spudich S, Harrington P, Price RW, Swanstrom R: Compartmentalized human immunodeficiency virus type 1 originates from long-lived cells in some subjects with HIV-1-associated dementia. PLoS Pathog 2009, 5(4):e1000395.

27. Zlokovic BV: Neurodegeneration and the neurovascular unit. Nat Med 2010, 16(12):1370-1371.

28. Aguilera KY, Brekken RA: Recruitment and retention: factors that affect pericyte migration. Cell Mol Life Sci: CMLS 2014, 71(2):299-309.

29. An SF, Groves M, Gray F, Scaravilli F: Early entry and widespread cellula involvement of HIV-1 DNA in brains of HIV-1 positive asymptomatic individuals. J Neuropathol Exp Neurol 1999, 58(11):1156-1162.

30. Meltzer MS, Skillman DR, Gomatos PJ, Kalter DC, Gendelman HE: Role of mononuclear phagocytes in the pathogenesis of human immunodeficiency virus infection. Annu Rev Immunol 1990, 8:169-194.

31. Nottet HS, Persidsky Y, Sasseville VG, Nukuna AN, Bock P, Zhai QH, Sharer LR, McComb RD, Swindells S, Soderland C, Gendelman HE: Mechanisms for the 
transendothelial migration of HIV-1-infected monocytes into brain. J Immunol 1996, 156(3):1284-1295.

32. Toborek M, Lee YW, Pu H, Malecki A, Flora G, Garrido R, Hennig B, Bauer HC, Nath A: HIV-Tat protein induces oxidative and inflammatory pathways in brain endothelium. J Neurochem 2003, 84(1):169-179.

33. Ensoli B, Buonaguro L, Barillari G, Fiorelli V, Gendelman R, Morgan RA, Wingfield P, Gallo RC: Release, uptake, and effects of extracellular human immunodeficiency virus type 1 Tat protein on cell growth and viral transactivation. J Virol 1993, 67(1):277-287.

34. Hudson L, Liu J, Nath A, Jones M, Raghavan R, Narayan O, Male D, Everall I: Detection of the human immunodeficiency virus regulatory protein tat in CNS tissues. J Neurovirol 2000, 6(2):145-155.

35. Johnson TP, Patel K, Johnson KR, Maric D, Calabresi PA, Hasbun R, Nath A: Induction of IL-17 and nonclassical T-cell activation by HIV-Tat protein. Proc Natl Acad Sci U S A 2013, 110(33):13588-13593.

36. Bachani M, Sacktor N, MCArthur JC, Nath A, Rumbaugh J: Detection of anti-tat antibodies in CSF of individuals with HIV-associated neurocognitive disorders. J Neurovirol 2013, 19(1):82-88.

37. Andras IE, Pu H, Deli MA, Nath A, Hennig B, Toborek M: HIV-1 Tat protein alters tight junction protein expression and distribution in cultured brain endothelial cells. J Neurosci Res 2003, 74(2):255-265.

38. Xu R, Feng X, Xie X, Zhang J, Wu D, Xu L: HIV-1 Tat protein increases the permeability of brain endothelial cells by both inhibiting occludin expression and cleaving occludin via matrix metalloproteinase-9. Brain Res 2012, 1436:13-19.

39. Kim TA, Avraham HK, Koh YH, Jiang S, Park IW, Avraham S: HIV-1 Tatmediated apoptosis in human brain microvascular endothelial cells. $\mathrm{J}$ Immunol 2003, 170(5):2629-2637.

40. Eugenin EA, Osiecki K, Lopez L, Goldstein H, Calderon TM, Berman JW: CCL2/monocyte chemoattractant protein-1 mediates enhanced transmigration of human immunodeficiency virus (HIV)-infected leukocytes across the blood-brain barrier: a potential mechanism of HIV-CNS invasion and NeuroAIDS. J Neurosci 2006, 26(4):1098-1106.

41. Moore JP, McKeating JA, Weiss RA, Sattentau QJ: Dissociation of gp120 from HIV-1 virions induced by soluble CD4. Science 1990, 250(4984):1139-1142.

42. Toneatto S, Finco O, van der Putten H, Abrignani S, Annunziata P: Evidence of blood-brain barrier alteration and activation in HIV-1 gp120 transgenic mice. Aids 1999, 13(17):2343-2348.

43. Chaudhuri A, Duan F, Morsey B, Persidsky Y, Kanmogne GD: HIV-1 activates proinflammatory and interferon-inducible genes in human brain microvascular endothelial cells: putative mechanisms of blood-brain barrier dysfunction. J Cerebr Blood Flow Metabol 2008, 28(4):697-711.

44. Kanmogne GD, Schall K, Leibhart J, Knipe B, Gendelman HE, Persidsky Y: HIV-1 gp120 compromises blood-brain barrier integrity and enhances monocyte migration across blood-brain barrier: implication for viral neuropathogenesis. J Cereb Blood Flow Metab: Official J Int Soc Cereb Blood Flow Metab 2007, 27(1):123-134.

45. Stins MF, Shen $Y$, Huang SH, Gilles F, Kalra VK, Kim KS: Gp120 activates children's brain endothelial cells via CD4. J Neurovirol 2001, 7(2):125-134.

46. Khan NA, Di Cello F, Stins M, Kim KS: Gp120-mediated cytotoxicity of human brain microvascular endothelial cells is dependent on p38 mitogen-activated protein kinase activation. J Neurovirol 2007, 13(3):242-251.

47. Everall IP, Luthert PJ, Lantos PL: Neuronal number and volume alterations in the neocortex of HIV infected individuals. J Neurol Neurosurg Psychiatry 1993, 56(5):481-486

48. Cull-Candy S, Brickley S, Farrant M: NMDA receptor subunits: diversity, development and disease. Curr Opin Neurobiol 2001, 11(3):327-335.

49. Hayashi H, Campenot RB, Vance DE, Vance JE: Apolipoprotein E-containing lipoproteins protect neurons from apoptosis via a signaling pathway involving low-density lipoprotein receptor-related protein-1. J Neurosci 2007, 27(8):1933-1941.

50. Girault JA, Greengard P: The neurobiology of dopamine signaling. Arch Neurol 2004, 61(5):641-644.

51. Chang L, Wang GJ, Volkow ND, Ernst T, Telang F, Logan J, Fowler JS: Decreased brain dopamine transporters are related to cognitive deficits in HIV patients with or without cocaine abuse. Neuroimage 2008, 42(2):869-878

52. Bardi G, Sengupta $R$, Khan MZ, Patel JP, Meucci O: Human immunodeficiency virus gp120-induced apoptosis of human neuroblastoma cells in the absence of CXCR4 internalization. J Neuroviro/ 2006, 12(3):211-218.

53. Toggas SM, Masliah E, Rockenstein EM, Rall GF, Abraham CR, Mucke L: Central nervous system damage produced by expression of the HIV-1 coat protein gp120 in transgenic mice. Nature 1994, 367(6459):188-193.

54. Lannuzel A, Lledo PM, Lamghitnia HO, Vincent JD, Tardieu M: HIV-1 envelope proteins gp120 and gp160 potentiate NMDA-induced [Ca2+]i increase, alter $[\mathrm{Ca} 2+] \mathrm{i}$ homeostasis and induce neurotoxicity in human embryonic neurons. Eur J Neurosci 1995, 7(11):2285-2293.

55. Catani MV, Corasaniti MT, Navarra M, Nistico G, Finazzi-Agro A, Melino G: gp120 induces cell death in human neuroblastoma cells through the CXCR4 and CCR5 chemokine receptors. J Neurochem 2000, 74(6):2373-2379.

56. Kaul M, Lipton SA: Chemokines and activated macrophages in HIV gp120-induced neuronal apoptosis. Proc Natl Acad Sci U S A 1999 96(14):8212-8216.

57. D'Hooge R, Franck F, Mucke L, De Deyn PP: Age-related behavioural deficits in transgenic mice expressing the HIV-1 coat protein gp120. Eur J Neurosci 1999, 11(12):4398-4402.

58. Chalasani SH, Baribaud F, Coughlan CM, Sunshine MJ, Lee VM, Doms RW Littman DR, Raper JA: The chemokine stromal cell-derived factor-1 promotes the survival of embryonic retinal ganglion cells. J Neurosci 2003, 23(11):4601-4612.

59. Khan MZ, Brandimarti R, Musser BJ, Resue DM, Fatatis A, Meucci O: The chemokine receptor CXCR4 regulates cell-cycle proteins in neurons. J Neurovirol 2003, 9(3):300-314.

60. Zhang K, McQuibban GA, Silva C, Butler GS, Johnston JB, Holden J, Clark-Lewis I, Overall CM, Power C: HIV-induced metalloproteinase processing of the chemokine stromal cell derived factor- 1 causes neurodegeneration. Nat Neurosci 2003, 6(10):1064-1071.

61. Ballester LY, Capo-Velez CM, Garcia-Beltran WF, Ramos FM, Vazquez-Rosa E, Rios R, Mercado JR, Melendez RI, Lasalde-Dominicci JA: Up-regulation of the neuronal nicotinic receptor alpha7 by HIV glycoprotein 120: potential implications for HIV-associated neurocognitive disorder J Biol Chem 2012, 287(5):3079-3086.

62. Nath A, Psooy K, Martin C, Knudsen B, Magnuson DS, Haughey N, Geiger JD: Identification of a human immunodeficiency virus type 1 Tat epitope that is neuroexcitatory and neurotoxic. J Virol 1996, 70(3):1475-1480.

63. Haughey NJ, Holden CP, Nath A, Geiger JD: Involvement of inositol 1,4,5-trisphosphate-regulated stores of intracellular calcium in calcium dysregulation and neuron cell death caused by HIV-1 protein tat. J Neurochem 1999, 73(4):1363-1374.

64. Liu Y, Jones M, Hingtgen CM, Bu G, Laribee N, Tanzi RE, Moir RD, Nath A, He JJ: Uptake of HIV-1 tat protein mediated by low-density lipoprotein receptor-related protein disrupts the neuronal metabolic balance of the receptor ligands. Nat Med 2000, 6(12):1380-1387.

65. Eugenin EA, King JE, Nath A, Calderon TM, Zukin RS, Bennett MV, Berman JW: HIV-tat induces formation of an LRP-PSD-95- NMDAR-nNOS complex that promotes apoptosis in neurons and astrocytes. Proc Natl Acad Sci U S A 2007, 104(9):3438-3443.

66. Chang JR, Mukerjee R, Bagashev A, Del Valle L, Chabrashvili T, Hawkins BJ, He JJ, Sawaya BE: HIV-1 Tat protein promotes neuronal dysfunction through disruption of microRNAs. J Biol Chem 2011, 286(47):41125-41134.

67. Zhu J, Ananthan S, Mactutus CF, Booze RM: Recombinant human immunodeficiency virus-1 transactivator of transcription 1-86 allosterically modulates dopamine transporter activity. Synapse (New York, NY) 2011, 65(11):1251-1254.

68. Patel CA, Mukhtar M, Pomerantz RJ: Human Immunodeficiency Virus Type $1 \mathrm{Vpr}$ induces apoptosis in human neuronal cells. J Virol 2000, 74(20):9717-9726.

69. Trillo-Pazos G, McFarlane-Abdulla E, Campbell IC, Pilkington GJ, Everall IP: Recombinant nef HIV-IIIB protein is toxic to human neurons in culture. Brain Res 2000, 864(2):315-326.

70. Ewart GD, Sutherland T, Gage PW, Cox GB: The Vpu protein of human immunodeficiency virus type 1 forms cation-selective ion channels. J Virol 1996, 70(10):7108-7115.

71. Akay C, Lindl KA, Shyam N, Nabet B, Goenaga-Vazquez Y, Ruzbarsky J, Wang $Y$, Kolson DL, Jordan-Sciutto KL: Activation status of integrated stress response pathways in neurones and astrocytes of HIV-associated neurocognitive disorders (HAND) cortex. Neuropathol Appl Neurobiol 2012, 38(2):175-200. 
72. Achim CL, Adame A, Dumaop W, Everall IP, Masliah E, Neurobehavioral Research C: Increased accumulation of intraneuronal amyloid beta in HIV-infected patients. J Neuroimmune Pharmacol 2009, 4(2):190-199.

73. Fine SM, Angel RA, Perry SW, Epstein LG, Rothstein JD, Dewhurst S, Gelbard HA: Tumor necrosis factor alpha inhibits glutamate uptake by primary human astrocytes. Implications for pathogenesis of HIV-1 dementia. J Biol Chem 1996, 271(26):15303-15306.

74. Marchetti L, Klein M, Schlett K, Pfizenmaier K, Eisel ULM: Tumor necrosis factor (TNF)-mediated neuroprotection against glutamate-induced excitotoxicity is enhanced by $\mathrm{N}$-methyl-D-aspartate receptor activation. Essential role of a TNF receptor 2-mediated phosphatidylinositol 3-kinase-dependent NF-kappa B pathway. J Biol Chem 2004, 279(31):32869-32881.

75. Cheung R, Ravyn V, Wang L, Ptasznik A, Collman RG: Signaling mechanism of HIV-1 gp120 and virion-induced IL-1beta release in primary human macrophages. J Immuno/ 2008, 180(10):6675-6684

76. Ye L, Huang $Y$, Zhao L, Li Y, Sun L, Zhou Y, Qian G, Zheng JC: IL-1 $\beta$ and TNF-a induce neurotoxicity through glutamate production: a potential role for neuronal glutaminase. J Neurochem 2013, 125(6):897-908

77. Yeung MC, Pulliam L, Lau AS: The HIV envelope protein gp120 is toxic to human brain-cell cultures through the induction of interleukin- 6 and tumor necrosis factor-alpha. AIDS (London, England) 1995, 9(2):137-143.

78. Rho MB, Wesselingh S, Glass JD, McArthur JC, Choi S, Griffin J, Tyor WR: A potential role for interferon-alpha in the pathogenesis of HIV-associated dementia. Brain Behav Immun 1995, 9(4):366-377.

79. Zhao L, Huang Y, Tian C, Taylor L, Curthoys N, Wang Y, Vernon H, Zheng J: Interferon-alpha regulates glutaminase 1 promoter through STAT1 phosphorylation: relevance to HIV-1 associated neurocognitive disorders. PLoS One 2012, 7(3):e32995.

80. Kerr SJ, Armati PJ, Guillemin GJ, Brew BJ: Chronic exposure of human neurons to quinolinic acid results in neuronal changes consistent with AIDS dementia complex. AIDS (London, England) 1998, 12(4):355-363.

81. Gelbard HA, Nottet HS, Swindells S, Jett M, Dzenko KA, Genis P, White R, Wang L, Choi YB, Zhang D: Platelet-activating factor: a candidate human immunodeficiency virus type 1-induced neurotoxin. J Virol 1994 68(7):4628-4635.

82. Rock RB, Gekker G, Hu S, Sheng WS, Cheeran M, Lokensgard JR, Peterson PK: Role of microglia in central nervous system infections. Clin Microbiol Rev 2004, 17(4):942-964. table of contents.

83. Ghorpade A, Persidsky Y, Swindells S, Borgmann K, Persidsky R, Holter S, Cotter R, Gendelman HE: Neuroinflammatory responses from microglia recovered from HIV-1-infected and seronegative subjects. $J$ Neuroimmunol 2005, 163(1-2):145-156.

84. Huang Y, Zhao L, Jia B, Wu L, Li Y, Curthoys N, Zheng JC: Glutaminase dysregulation in HIV-1-infected human microglia mediates neurotoxicity: relevant to HIV-1-associated neurocognitive disorders. J Neurosci 2011, 31(42):15195-15204.

85. Garvey LJ, Pavese N, Politis M, Ramlackhansingh A, Brooks DJ, TaylorRobinson SD, Winston A: Increased microglia activation in neurologically asymptomatic HIV-infected patients receiving effective ART. Aids 2014, 28(1):67-72

86. D'Aversa TG, Yu KO, Berman JW: Expression of chemokines by human fetal microglia after treatment with the human immunodeficiency virus type 1 protein Tat. J Neurovirol 2004, 10(2):86-97.

87. Meucci O, Fatatis A, Simen AA, Miller RJ: Expression of CX3CR1 chemokine receptors on neurons and their role in neuronal survival. Proc Natl Acad Sci U S A 2000, 97(14):8075-8080.

88. Perez-Alvarez A, Araque A: Astrocyte-neuron interaction at tripartite synapses. Curr Drug Targets 2013, 14(11):1220-1224.

89. Navarrete M, Perea G, Maglio L, Pastor J, Garcia de Sola R, Araque A: Astrocyte calcium signal and gliotransmission in human brain tissue. Cereb Cortex 2013, 23(5):1240-1246.

90. Eugenin EA, Clements JE, Zink MC, Berman JW: Human immunodeficiency virus infection of human astrocytes disrupts blood-brain barrier integrity by a gap junction-dependent mechanism. J Neurosci 2011, 31(26):9456-9465.

91. Churchill MJ, Wesselingh SL, Cowley D, Pardo CA, McArthur JC, Brew BJ, Gorry PR: Extensive astrocyte infection is prominent in human immunodeficiency virus-associated dementia. Ann Neurol 2009, 66(2):253-258
92. Conant K, Garzino-Demo A, Nath A, McArthur JC, Halliday W, Power C, Gallo RC, Major EO: Induction of monocyte chemoattractant protein-1 in HIV-1 Tat-stimulated astrocytes and elevation in AIDS dementia. Proc Natl Acad Sci U S A 1998, 95(6):3117-3121.

93. Nath A, Conant K, Chen P, Scott C, Major EO: Transient exposure to HIV-1 Tat protein results in cytokine production in macrophages and astrocytes. a hit and run phenomenon. J Biol Chem 1999, 274(24):17098-17102.

94. Liu X, Jana M, Dasgupta S, Koka S, He J, Wood C, Pahan K: Human immunodeficiency virus type 1 (HIV-1) tat induces nitric-oxide synthase in human astroglia. J Biol Chem 2002, 277(42):39312-39319.

95. Bethel-Brown C, Yao H, Hu G, Buch S: Platelet-derived growth factor (PDGF)-BB-mediated induction of monocyte chemoattractant protein 1 in human astrocytes: implications for HIV-associated neuroinflammation. J Neuroinflammation 2012, 9:262

96. Ju SM, Song HY, Lee JA, Lee SJ, Choi SY, Park J: Extracellular HIV-1 Tat up-regulates expression of matrix metalloproteinase- 9 via a MAPK-NF-kappaB dependent pathway in human astrocytes. Exp Mol Med 2009, 41(2):86-93.

97. Yeung MC, Pulliam L, Lau AS: The HIV envelope protein gp120 is toxic to human brain-cell cultures through the induction of interleukin- 6 and tumor necrosis factor-alpha. Aids 1995, 9(2):137-143.

98. Holden $\mathrm{CP}$, Haughey NJ, Nath A, Geiger JD: Role of $\mathrm{Na}+/ \mathrm{H}+$ exchangers, excitatory amino acid receptors and voltage-operated $\mathrm{Ca} 2+$ channels in human immunodeficiency virus type 1 gp120-mediated increases in intracellular Ca2+ in human neurons and astrocytes. Neuroscience 1999, 91(4):1369-1378

99. Wang Z, Trillo-Pazos G, Kim SY, Canki M, Morgello S, Sharer LR, Gelbard HA, Su ZZ, Kang DC, Brooks Al, Fisher PB, Volsky DJ: Effects of human immunodeficiency virus type 1 on astrocyte gene expression and function: potential role in neuropathogenesis. J Neurovirol 2004, 10(Suppl 1):25-32.

100. Fernandes SP, Edwards TM, Ng KT, Robinson SR: HIV-1 protein gp120 rapidly impairs memory in chicks by interrupting the glutamateglutamine cycle. Neurobiol Learn Mem 2007, 87(1):1-8.

101. Peng F, Dhillon N, Callen S, Yao H, Bokhari S, Zhu X, Baydoun HH, Buch S: Platelet-derived growth factor protects neurons against gp120-mediated toxicity. J Neurovirol 2008, 14(1):62-72.

102. Peng F, Yao H, Akturk HK, Buch S: Platelet-derived growth factor CC-mediated neuroprotection against HIV Tat involves TRPCmediated inactivation of GSK 3beta. PLoS One 2012, 7(10):e47572

103. Ashutosh, Chao C, Borgmann K, Brew K, Ghorpade A: Tissue inhibitor of metalloproteinases- 1 protects human neurons from staurosporine and HIV-1-induced apoptosis: mechanisms and relevance to HIV-1-associated dementia. Cell Death Dis 2012, 3:e332.

104. Reddy PV, Gandhi N, Samikkannu T, Saiyed Z, Agudelo M, Yndart A, Khatavkar P, Nair MP: HIV-1 gp120 induces antioxidant response element-mediated expression in primary astrocytes: role in HIV associated neurocognitive disorder. Neurochem Int 2012, 61(5):807-814.

105. Meucci O, Fatatis A, Simen AA, Bushell TJ, Gray PW, Miller RJ: Chemokines regulate hippocampal neuronal signaling and gp120 neurotoxicity. Proc Natl Acad Sci U S A 1998, 95(24):14500-14505.

106. Tong N, Perry SW, Zhang Q, James HJ, Guo H, Brooks A, Bal H, Kinnear SA, Fine S, Epstein LG, Dairaghi D, Schall TJ, Gendelman HE, Dewhurst S, Sharewr LR, Gelbard HA: Neuronal fractalkine expression in HIV-1 encephalitis: roles for macrophage recruitment and neuroprotection in the central nervous system. J Immunol 2000, 164(3):1333-1339.

107. Chun H, Hao W, Honghai Z, Ning L, Yasong W, Chen D: CCL3L1 prevents gp120-induced neuron death via the CREB cell signaling pathway. Brain Res 2009, 1257:75-88.

108. Dean M, Carrington M, Winkler C, Huttley GA, Smith MW, Allikmets R, Goedert JJ, Buchbinder SP, Vittinghoff E, Gomperts E, Donfield S, Vlahov D, Kaslow R, Saah A, Rinaldo C, Detels R, O'Brien SJ: Genetic restriction of HIV-1 infection and progression to AIDS by a deletion allele of the CKR5 structural gene. Hemophilia Growth and Development Study, Multicenter AIDS Cohort Study, Multicenter Hemophilia Cohort Study, San Francisco City Cohort, ALIVE. Sci (New York, NY) 1996, 273(5283):1856-1862.

109. Gonzalez E, Kulkarni H, Bolivar H, Mangano A, Sanchez R, Catano G, Nibbs RJ, Freedman BI, Quinones MP, Bamshad MJ, Murthy KK, Rovin BH, Bradley W, Clark RA, Anderson SA, O'Connell RJ, Agan BK, Ahuja SS, Bologna R, Sen L, 
Dolan MJ, Ahuja SK: The influence of CCL3L1 gene-containing segmental duplications on HIV-1/AIDS susceptibility. Sci (New York, NY) 2005, 307(5714):1434-1440.

110. Smith MW, Dean M, Carrington M, Winkler C, Huttley GA, Lomb DA, Goedert JJ, O'Brien TR, Jacobson LP, Kaslow R, Buchbinder S, Vittinghoff E, Vlahov D, Hoots K, Hoots K, Hilgartner MW, O'Brien SJ: Contrasting genetic influence of CCR2 and CCR5 variants on HIV-1 infection and disease progression. Hemophilia Growth and Development Study (HGDS), Multicenter AIDS Cohort Study (MACS), Multicenter Hemophilia Cohort Study (MHCS), San Francisco City Cohort. Sci (New York, NY) 1997, 277(5328):959-965.

111. Singh KK, Ellis RJ, Marquie-Beck J, Letendre S, Heaton RK, Grant I, Spector S. CCR2 polymorphisms affect neuropsychological impairment in HIV-1infected adults. J Neuroimmunol 2004, 157(1-2):185-192.

112. Quasney MW, Zhang Q, Sargent S, Mynatt M, Glass J, McArthur J: Increased frequency of the tumor necrosis factor-alpha-308 A allele in adults with human immunodeficiency virus dementia. Ann Neurol 2001 50(2):157-162

113. Gonzalez E, Rovin BH, Sen L, Cooke G, Dhanda R, Mummidi S, Kulkarni H, Bamshad MJ, Telles V, Anderson SA, Walter EA, Stephan KT, Deucher M, Mangano A, Bologna R, Ahuja SS, Dolan MJ, Ahuja SK: HIV-1 infection and AIDS dementia are influenced by a mutant MCP-1 allele linked to increased monocyte infiltration of tissues and MCP-1 levels. Proc Natl Acad Sci U S A 2002, 99(21):13795-13800.

114. El-Bassel N, Shaw SA, Dasgupta A, Strathdee SA: Drug use as a driver of HIV risks: re-emerging and emerging issues. Curr Opin HIV AIDS 2014, 9(2):150-155.

115. Substance Abuse and Mental Health Services Administration: Results from the 2007 National survey on drug use and health: National findings. (Office of Applied Studies, NSDUH series H-34, DHHS Publication No. SMA 08-4343). Rockville, MD: Substance Abuse and Mental Health Services Administration, Office of Applied Studies - U.S. Department of Health and Human Services; 2008.

116. Pert CB, Snyder SH: Opiate receptor: demonstration in nervous tissue. Science 1973, 179(4077):1011-1014.

117. Turchan-Cholewo J, Dimayuga FO, Ding Q, Keller JN, Hauser KF, Knapp PE, Bruce-Keller AJ: Cell-specific actions of HIV-Tat and morphine on opioid receptor expression in glia. J Neurosci Res 2008, 86(9):2100-2110.

118. Fitting S, Xu R, Bull C, Buch SK, El-Hage N, Nath A, Knapp PE, Hauser KF: Interactive comorbidity between opioid drug abuse and HIV-1 Tat: chronic exposure augments spine loss and sublethal dendritic pathology in striatal neurons. Am J Pathol 2010, 177(3):1397-1410.

119. Malik S, Khalique H, Buch S, Seth P: A growth factor attenuates HIV-1 Tat and morphine induced damage to human neurons: implication in HIV/ AIDS-drug abuse cases. PLoS One 2011, 6(3):e18116.

120. Hu S, Sheng WS, Lokensgard JR, Peterson PK: Morphine potentiates HIV-1 gp120-induced neuronal apoptosis. J Infect Dis 2005, 191(6):886-889.

121. Bandaru W, Patel N, Ewaleifoh O, Haughey NJ: A failure to normalize biochemical and metabolic insults during morphine withdrawal disrupts synaptic repair in mice transgenic for HIV-gp120. J Neuroimmune Pharmacol 2011, 6(4):640-649.

122. El-Hage N, Wu G, Wang J, Ambati J, Knapp PE, Reed JL, Bruce-Keller AJ, Hauser KF: HIV-1 Tat and opiate-induced changes in astrocytes promote chemotaxis of microglia through the expression of MCP-1 and alternative chemokines. Glia 2006, 53(2):132-146.

123. Arango JC, Simmonds P, Brettle RP, Bell JE: Does drug abuse influence the microglial response in AIDS and HIV encephalitis? Aids 2004, 18(Suppl 1):S69-S74

124. Guo CJ, Li Y, Tian S, Wang X, Douglas SD, Ho WZ: Morphine enhances HIV infection of human blood mononuclear phagocytes through modulation of beta-chemokines and CCR5 receptor. J Investig Med 2002, 50(6):435-442.

125. Wang X, Ye L, Zhou Y, Liu MQ, Zhou DJ, Ho WZ: Inhibition of anti-HIV microRNA expression: a mechanism for opioid-mediated enhancement of HIV infection of monocytes. Am J Pathol 2011, 178(1):41-47.

126. Kumar R, Torres C, Yamamura Y, Rodriguez I, Martinez M, Staprans S, Donahoe RM, Kraiselburd E, Stephens EB, Kumar A: Modulation by morphine of viral set point in rhesus macaques infected with simian immunodeficiency virus and simian-human immunodeficiency virus. J Virol 2004, 78(20):11425-11428.

127. Langford D, Adame A, Grigorian A, Grant I, McCutchan JA, Ellis RJ, Marcotte $T D$, Masliah E: Patterns of selective neuronal damage in methamphetamine-user AIDS patients. J Acquir Immune Defic Syndr 2003, 34(5):467-474
128. Maragos WF, Young KL, Turchan JT, Guseva M, Pauly JR, Nath A, Cass WA: Human immunodeficiency virus-1 Tat protein and methamphetamine interact synergistically to impair striatal dopaminergic function. J Neurochem 2002, 83(4):955-963.

129. Qi L, Gang L, Hang KW, Ling CH, Xiaofeng Z, Zhen L, Wai YD, Sang PW: Programmed neuronal cell death induced by HIV-1 tat and methamphetamine. Microsc Res Tech 2011, 74(12):1139-1144.

130. Shah A, Silverstein PS, Kumar S, Singh DP, Kumar A: Synergistic cooperation between methamphetamine and HIV-1 gsp120 through the P13K/Akt pathway induces IL-6 but not IL-8 expression in astrocytes. PLoS One 2012, 7(12):e52060.

131. Sharma A, Hu XT, Napier TC, Al-Harthi L: Methamphetamine and HIV-1 Tat down regulate beta-catenin signaling: implications for methampetamine abuse and HIV-1 co-morbidity. J Neuroimmune Pharmacol 2011, 6(4):597-607.

132. Ellis RJ, Childers ME, Cherner M, Lazzaretto D, Letendre S, Grant I: Increased human immunodeficiency virus loads in active methamphetamine users are explained by reduced effectiveness of antiretroviral therapy. $J$ Infect Dis 2003, 188(12):1820-1826.

133. Talloczy Z, Martinez J, Joset D, Ray Y, Gacser A, Toussi S, Mizushima N, Nosanchuk JD, Goldstein H, Loike J, Sulzer D, Santambrogio L: Methamphetamine inhibits antigen processing, presentation, and phagocytosis. PLoS Pathog 2008, 4(2):e28.

134. Liang H, Wang X, Chen H, Song L, Ye L, Wang SH, Wang YJ, Zhou L, Ho WZ: Methamphetamine enhances HIV infection of macrophages. Am J Pathol 2008, 172(6):1617-1624.

135. Toussi SS, Joseph A, Zheng JH, Dutta M, Santambrogio L, Goldstein H: Short communication: Methamphetamine treatment increases in vitro and in vivo HIV replication. AIDS Res Hum Retroviruses 2009, 25(11):1117-1121.

136. Aksenov MY, Aksenova MV, Nath A, Ray PD, Mactutus CF, Booze RM: Cocaine-mediated enhancement of Tat toxicity in rat hippocampal cell cultures: the role of oxidative stress and D1 dopamine receptor. Neurotoxicology 2006, 27(2):217-228.

137. Dhillon NK, Williams R, Peng F, Tsai YJ, Dhillon S, Nicolay B, Gadgil M, Kumar A, Buch SJ: Cocaine-mediated enhancement of virus replication in macrophages: implications for human immunodeficiency virus-associated dementia. J Neurovirol 2007, 13(6):483-495.

138. Yao H, Kim K, Duan M, Hayashi T, Guo M, Morgello S, Prat A, Wang J, Su TP, Buch S: Cocaine hijacks sigma1 receptor to initiate induction of activated leukocyte cell adhesion molecule: implication for increased monocyte adhesion and migration in the CNS. J Neurosci 2011, 31(16):5942-5955.

139. Hu S, Sheng WS, Rock RB: CB2 Receptor agonists protect human dopaminergic neurons against damage from HIV-1 gp120. PLoS One 2013, 8(10):e77577.

140. Avraham HK, Jiang S, Fu Y, Rockenstein E, Makriyannis A, Zvonok A, Masliah E, Avraham S: The cannabinoid CB2 receptor agonist AM1241 enhances neurogenesis in GFAP/Gp120 transgenic mice displaying deficits in neurogenesis. Br J Pharmacol 2014, 171(2):468-479.

141. Hemelaar J, Gouws E, Ghys PD, Osmanov S: Isolation W-UNfH, Characterisation: Global trends in molecular epidemiology of HIV-1 during 2000-2007. Aids 2011, 25(5):679-689.

142. Tebit DM, Nankya I, Arts EJ, Gao Y: HIV diversity, recombination and disease progression: how does fitness "fit" into the puzzle? AIDS Rev 2007, 9(2):75-87.

143. Gupta JD, Satishchandra P, Gopukumar K, Wilkie F, Waldrop-Valverde D, Ellis R, Ownby R, Subbakrishna DK, Desai A, Kamat A, Ravi V, Rao BS, Satish KS, Kumar $M$ : Neuropsychological deficits in human immunodeficiency virus type 1 clade C-seropositive adults from South India. J Neurovirol 2007, 13(3):195-202

144. Satishchandra P, Nalini A, Gourie-Devi M, Khanna N, Santosh V, Ravi V, Desai A, Chandramuki A, Jayakumar PN, Shankar SK: Profile of neurologic disorders associated with HIV/AIDS from Bangalore, south India (1989-96). Indian J Med Res 2000, 111:14-23.

145. Langford TD, Letendre SL, Larrea GJ, Masliah E: Changing patterns in the neuropathogenesis of HIV during the HAART era. Brain Pathol 2003, 13(2):195-210.

146. Sacktor N, Lyles RH, Skolasky R, Kleeberger C, Selnes OA, Miller EN, Becker JT, Cohen B, McArthur JC: HIV-associated neurologic disease incidence changes: multicenter AIDS Cohort Study, 1990-1998. Neurology 2001, 56(2):257-260.

147. Ranga U, Shankarappa R, Siddappa NB, Ramakrishna L, Nagendran R, Mahalingam M, Mahadevan A, Jayasuryan N, Satishchandra P, Shankar SK, 
Prasad VR: Tat protein of human immunodeficiency virus type 1 subtype C strains is a defective chemokine. J Virol 2004, 78(5):2586-2590.

148. Albini, Ferrini S, Benelli R, Sforzini S, Giunciuglio D, Aluigi MG: HIV-1 Tat protein mimicry of chemokines. Proc National Academy of Sciences - PNAS 1998, 95(22):13153-13158.

149. Mishra M, Vetrivel S, Siddappa NB, Ranga U, Seth P: Clade specific differences in neurotoxicity of human immunodeficiency virus-1 B and $C$ Tat of human neurons: significance of dicysteine C30C31 motif. Ann Neurol 2008, 63(3):366-376.

150. Campbell GR, Watkins JD, Singh KK, Loret EP, Spector SA: Human immunodeficiency virus type 1 subtype $C$ Tat fails to induce intracellular calcium flux and induces reduced tumor necrosis factor production from monocytes. J Virol 2007, 81(11):5919-5928.

151. Rao VR, Neogi U, Talboom JS, Padilla L, Rahman M, Fritz-French C, Gonzalez-Ramirez S, Verma A, Wood C, Ruprecht RM, Ranga U, Azim T, Joska J, Eugenin E, Shet A, Bimonte-Nelson H, Tyor WR, Prasad VR: Clade C HIV-1 isolates circulating in Southern Africa exhibit a greater frequency of dicysteine motif-containing Tat variants than those in Southeast Asia and cause increased neurovirulence. Retrovirology 2013, 10:61.

152. Li W, Huang Y, Reid R, Steiner J, Malpica-Llanos T, Darden TA, Shankar SK, Mahadevan A, Satishchandra P, Nath A: NMDA receptor activation by HIV-Tat protein is clade dependent. J Neurosci 2008, 28(47):12190-12198.

153. Gandhi N, Saiyed Z, Thangavel S, Rodriguez J, Rao KV, Nair MP: Differential effects of HIV type 1 clade B and clade C Tat protein on expression of proinflammatory and antiinflammatory cytokines by primary monocytes. AIDS Res Hum Retroviruses 2009, 25(7):691-699.

154. Wong JK, Campbell GR, Spector SA: Differential induction of interleukin-10 in monocytes by HIV-1 clade B and clade C Tat proteins. J Biol Chem 2010, 285(24):18319-18325.

155. Rao VR, Sas AR, Eugenin EA, Siddappa NB, Bimonte-Nelson H, Berman JW, Ranga U, Tyor WR, Prasad VR: HIV-1 clade-specific differences in the induction of neuropathogenesis. J Neurosci 2008, 28(40):10010-10016.

156. Gandhi N, Saiyed ZM, Napuri J, Samikkannu T, Reddy PV, Agudelo M, Khatavkar P, Saxena SK, Nair MP: Interactive role of human immunodeficiency virus type 1 (HIV-1) clade-specific Tat protein and cocaine in blood-brain barrier dysfunction: implications for HIV-1-associated neurocognitive disorder. J Neurovirol 2010, 16(4):294-305.

157. Samikkannu T, Saiyed ZM, Rao KV, Babu DK, Rodriquez JW, Papuashvili MN, Nair MP: Differential regulation of indoleamine-2,3-dioxygenase (IDO) by HIV type 1 clade B and C Tat protein. AIDS Res Hum Retroviruses 2009, 25(3):329-335.

158. Henderson $\mathrm{L}$, Sharma A, Monaco MC, Major EO, Al-Harthi L: Human immunodeficiency virus type 1 (HIV-1) transactivator of transcription through its intact core and cysteine-rich domains inhibits Wnt/beta-catenin signaling in astrocytes: relevance to HIV neuropathogenesis. J Neurosci 2012, 32(46):16306-16313.

159. Joska JA, Fincham DS, Stein DJ, Paul RH, Seedat S: Clinical correlates of HIV-associated neurocognitive disorders in South Africa. AIDS Behav 2010, 14(2):371-378

160. Joska JA, Westgarth-Taylor J, Myer L, Hoare J, Thomas KG, Combrinck M, Paul RH, Stein DJ, Flisher AJ: Characterization of HIV-Associated Neurocognitive Disorders among individuals starting antiretroviral therapy in South Africa. AIDS Behav 2011, 15(6):1197-1203.

161. Lawler K, Mosepele M, Ratcliffe S, Seloilwe E, Steele K, Nthobatsang R, Steenhoff A: Neurocognitive impairment among HIV-positive individuals in Botswana: a pilot study. J Int AIDS Soc 2010, 13:15.

162. Modi G, Hari K, Modi M, Mochan A: The frequency and profile of neurology in black South African HIV infected (clade C) patients - a hospital-based prospective audit. J Neurol Sci 2007, 254(1-2):60-64.

163. Bachu M, Yalla S, Asokan M, Verma A, Neogi U, Sharma S, Murali RV, Mukthey AB, Bhatt R, Chatterjee S, Rajan RE, Cheedarla N, Yadavalli VS, Mahadevan A, Shankar SK, Rajagopalan N, Shet A, Saravanan S, Balakrishnan P, Solomon S, Vajpayee M, Satish KS, Kundu TK, Jeang KT, Ranga U: Multiple NF-kappaB sites in HIV-1 subtype C long terminal repeat confer superior magnitude of transcription and thereby the enhanced viral predominance. J Biol Chem 2012, 287(53):44714-44735.

164. Shankarappa R, Chatterjee R, Learn GH, Neogi D, Ding M, Roy P, Ghosh A, Kingsley L, Harrison L, Mullins Jl, Gupta P: Human immunodeficiency virus type 1 env sequences from Calcutta in eastern India: identification of features that distinguish subtype $C$ sequences in India from other subtype C sequences. J Virol 2001, 75(21):10479-10487.
165. Dore GJ, McDonald A, Li Y, Kaldor JM, Brew BJ, National HIVSC: Marked improvement in survival following AIDS dementia complex in the era of highly active antiretroviral therapy. Aids 2003, 17(10):1539-1545.

166. Alkali NH, Bwala SA, Nyandaiti YW, Danesi MA: NeuroAIDS in sub-Saharan Africa: a clinical review. Ann Afr Med 2013, 12(1):1-10,

167. Heaton RK, Clifford DB, Franklin DR Jr. Woods SP, Ake C, Vaida F, Ellis RJ, Letendre SL, Marcotte TD, Atkinson JH, Rivera-Mindt M, Vigil OR, Taylor MJ, Collier AC, Marra CM, Gelman BB, McArthur JC, Morgello S, Simpsons DM, McCutchan JA, Abramson I, Gamst A, Fennema-Notestine C, Jernigan TL, Wong J, Grant I: HIV-associated neurocognitive disorders persist in the era of potent antiretroviral therapy: CHARTER Study. Neurology 2010, 75(23):2087-2096.

168. Kallianpur KJ, Shikuma C, Kirk GR, Shiramizu B, Valcour V, Chow D, Souza S, Nakamoto B, Sailasuta N: Peripheral blood HIV DNA is associated with atrophy of cerebellar and subcortical gray matter. Neurology 2013, 80(19):1792-1799.

169. McManus H, Li PC, Nolan D, Bloch M, Kiertiburanakul S, Choi JY, Mulhall B, Petoumenos K, Zhou J, Law M, Brew BJ, Wright E: Does use of antiretroviral therapy regimens with high central nervous system penetration improve survival in HIV-infected adults? HIV Med 2011, 12(10):610-619.

170. Dahl V, Lee E, Peterson J, Spudich SS, Leppla I, Sinclair E, Fuchs D, Palmer S, Price RW: Raltegravir treatment intensification does not alter cerebrospinal fluid HIV-1 infection or immunoactivation in subjects on suppressive therapy. J Infect Dis 2011, 204(12):1936-1945.

171. Vassallo M, Durant J, Biscay V, Lebrun-Frenay C, Dunais B, Laffon M, Harvey-Langton A, Cottalorda J, Ticchioni M, Carsenti H, Pradier C, Dellamonica P: Can high central nervous system penetrating antiretroviral regimens protect against the onset of HIV-associated neurocognitive disorders? Aids 2014, 28(4):493-501.

172. Follstaedt SC, Barber SA, Zink MC: Mechanisms of minocycline-induced suppression of simian immunodeficiency virus encephalitis: inhibition of apoptosis signal-regulating kinase 1. J Neurovirol 2008, 14(5):376-388

173. Nath A, Haughey NJ, Jones M, Anderson C, Bell JE, Geiger JD: Synergistic neurotoxicity by human immunodeficiency virus proteins Tat and gp120: protection by memantine. Ann Neurol 2000, 47(2):186-194.

174. Darbinian N, Khalili K, Amini S: Neuroprotective activity of pDING in response to HIV-1 Tat. J Cell Physiol 2014, 229(2):153-161.

175. Kang YJ, Digicaylioglu M, Russo R, Kaul M, Achim CL, Fletcher L, Masliah E, Lipton SA: Erythropoietin plus insulin-like growth factor-I protects against neuronal damage in a murine model of human immunodeficiency virusassociated neurocognitive disorders. Ann Neurol 2010, 68(3):342-352.

176. Mahajan SD, Aalinkeel R, Law WC, Reynolds JL, Nair BB, Sykes DE, Yong KT, Roy I, Prasad PN, Schwartz SA: Anti-HIV-1 nanotherapeutics: promises and challenges for the future. Int I Nanomedicine 2012, 7:5301-5314.

177. Dash PK, Gendelman HE, Roy U, Balkundi S, Alnouti Y, Mosley RL, Gelbard HA, McMillan J, Gorantla S, Poluektova LY: Long-acting nanoformulated antiretroviral therapy elicits potent antiretroviral and neuroprotective responses in HIV-1-infected humanized mice. Aids 2012, 26(17):2135-2144.

178. Spudich SS, Ances BM: Neurologic complications of HIV infection: highlights from the 2013 Conference on Retroviruses and Opportunistic Infections. Top Antivir Med 2013, 21(3):100-108.

doi:10.1186/1742-6405-11-13

Cite this article as: Rao et al.: Viral and cellular factors underlying neuropathogenesis in HIV associated neurocognitive disorders (HAND). AIDS Research and Therapy 2014 11:13. 